\title{
THE DISTRIBUTION OF HOUSEHOLD SAVINGS IN GERMANY
}

Jochen Späth ${ }^{1}$; Kai Daniel Schmid²

\begin{abstract}
Savings are, apart from inheritances and transfers, the corner stone for the accumulation of wealth. Against the background of rising economic inequality in industrialized countries and the ongoing assessment of its root causes, analyses of the distribution of savings along the income and wealth distribution are of high interest for the question on whether mutual stimulation between income flows and wealth stocks contributes to rising inequality. We analyze the extent of the concentration of household savings in Germany by estimating saving amounts, saving rates and shares in aggregate savings for different classes of household income and household wealth in Germany. Our calculations are based on the Sample Survey of Household Income and Expenditure (in German: Einkommens- und Verbrauchsstichprobe - EVS), a large sample containing more than 40,000 households in Germany. We show that the concentration of savings in Germany is substantial, as in 2013 the top income decile's share in aggregate savings amounts to about 60 percent, whereas the lower half of the income distribution actually does not save at all. Conditional on the distribution of wealth the concentration of savings is somewhat less pronounced, but still apparent. Over the years 2003 till 2013 we find an increase of the concentration of household savings across the income and wealth distribution. Finally, based on a set of assumptions, we look beyond the top income threshold underlying the EVS dataset (18,000 euros of monthly net household income) in order to estimate bias-corrected saving rates for the top income groups which are considerably higher than those that can be calculated with our data set alone. Using these corrected saving rates as input parameters for a macro simulation of the distribution of household incomes and savings we find that the aggregate saving rate increases by two to three percentage points compared to the estimate based on EVS data alone. Also, the top decile and percentile groups' shares in aggregate savings are substantially higher compared to the estimates solely based on EVS data.
\end{abstract}

\footnotetext{
${ }^{1}$ Corresponding author, email: jochen.spaeth@iaw.edu. We thank Rolf Kleimann, Stefan Bach and Tobias Brändle for helpful comments and support with regard to the data.

${ }^{2}$ Kai Daniel Schmid, Institute for Applied Economic Research (IAW), Tübingen.
} 


\title{
The Distribution of Household Savings in Germany
}

\author{
Jochen Späth* \\ Kai Daniel Schmid \\ Institute for Applied Economic Research (IAW), Tübingen
}

\begin{abstract}
Savings are, apart from inheritances and transfers, the corner stone for the accumulation of wealth. Against the background of rising economic inequality in industrialized countries and the ongoing assessment of its root causes, analyses of the distribution of savings along the income and wealth distribution are of high interest for the question on whether mutual stimulation between income flows and wealth stocks contributes to rising inequality. We analyze the extent of the concentration of household savings in Germany by estimating saving amounts, saving rates and shares in aggregate savings for different classes of household income and household wealth in Germany. Our calculations are based on the Sample Survey of Household Income and Expenditure (in German: Einkommens- und Verbrauchsstichprobe - EVS), a large sample containing more than 40,000 households in Germany. We show that the concentration of savings in Germany is substantial, as in 2013 the top income decile's share in aggregate savings amounts to about 60 percent, whereas the lower half of the income distribution actually does not save at all. Conditional on the distribution of wealth the concentration of savings is somewhat less pronounced, but still apparent. Over the years 2003 till 2013 we find an increase of the concentration of household savings across the income and wealth distribution. Finally, based on a set of assumptions, we look beyond the top income threshold underlying the EVS dataset $(18,000$ euros of monthly net household income) in order to estimate bias-corrected saving rates for the top income groups which are considerably higher than those that can be calculated with our data set alone. Using these corrected saving rates as input parameters for a macro simulation of the distribution of household incomes and savings we find that the aggregate saving rate increases by two to three percentage points compared to the estimate based on EVS data alone. Also, the top decile and percentile groups' shares in aggregate savings are substantially higher compared to the estimates solely based on EVS data.
\end{abstract}

Key words: Household Savings, Saving Rate, EVS, Administrative Data, Inequality, Endogenous Accumulation

JEL Code: D14, E21

* Corresponding author, email: jochen.spaeth@iaw.edu. We thank Rolf Kleimann, Stefan Bach and Tobias Brändle for helpful comments and support with regard to the data. 


\section{Table of Contents}

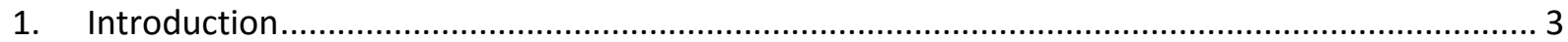

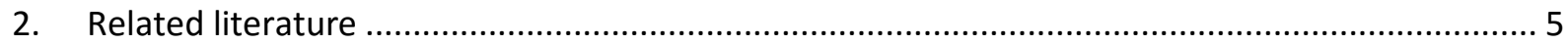

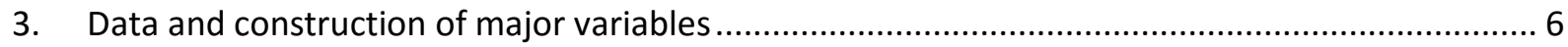

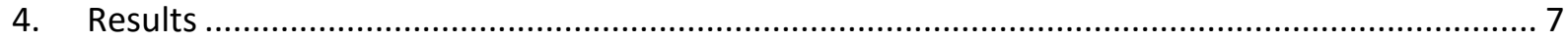

4.1. Household savings across the income distribution .................................................. 8

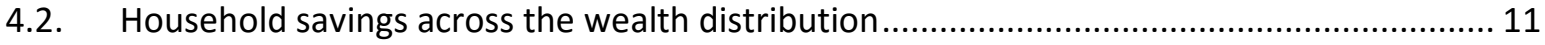

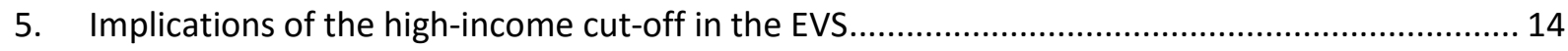

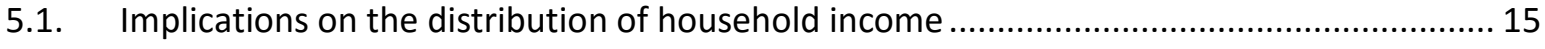

5.2. Implications on the distribution of household wealth ............................................ 17

5.3. Implications for the distribution of household savings ........................................... 18

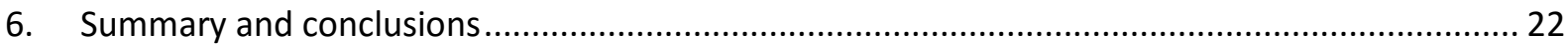

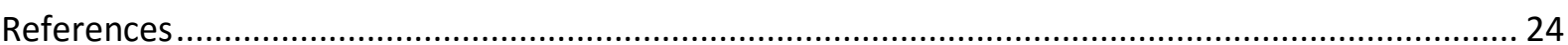

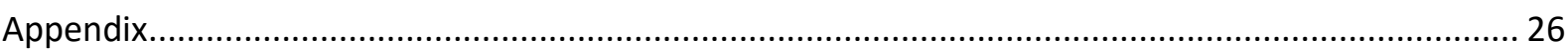




\section{Introduction}

Throughout the last decade there has been a lively debate among economists and policy makers about economic inequality in industrialized countries. Taking the recent rise in economic inequality as a starting point, a central aspect of this discussion has focused on the effects of inequality on economic development. In this vein, a number of studies point to a negative impact of inequality on economic growth. As an example, OECD (2015) finds that increasing inequality can hinder economic growth, as access to education and welfare are determined by peoples' economic positions. Also, according to IMF (2015), a raise in income in the upper income quintile is associated with reduced growth, whereas an increase in income in the lowest income quintile comes along with higher economic growth. Moreover, several studies point to a potential destabilizing effect of economic inequality on the society as a whole. Besides this, public acceptance of economic inequality is quite low in Germany. Mau and Heuer (2016), for example, provide evidence that the majority of Germans reject the unequal distribution of resources in Germany.

Next to the discussion of the potentially negative consequences of economic inequality among households it is important to understand the root causes of rising inequality. ${ }^{1}$ For Germany, there are a number of studies that discuss the impact of labor market developments (Brenke and Grabka 2011, Fuchs et al. 2012, IAW 2011 or Kalina and Weinkopf 2012) and changes in the distribution of capital income (Adler and Schmid 2013, Atkinson 2009, Horn et al. 2014, Drechsel-Grau et al. 2015) on the rise in market income inequality. In addition, there are analyses of the impact of the relevance of the tax and transfer system on the distribution of net income (Biewen and Juhasz 2012, Schmid and Stein 2013, Bach et al. 2013).

Closely connected to the impact of changes in the distribution of capital income is the question on whether mutual stimulation between income flows and wealth stocks contributes to rising inequality. Here, the distribution of household savings is of central relevance and its role is twofold. Apart from inheritances and transfers, savings are a major channel of wealth accumulation at the household level and able to explain a substantial part of changes in the distribution of wealth. Besides, changes in aggregate savings can affect macroeconomic growth through their implications on private consumption and the level and distribution of household debt. Thus, it is important to take a detailed look at the distribution of household savings when trying to assess the causes and consequences of rising economic inequality.

In an attempt to do so, researchers have started to identify and disentangle the above mentioned mechanisms and to evaluate their relevance in explaining distributional dynamics. One way to approach these issues is achieved by constructing models of endogenous accumulation such as in Aspromourgos (2015), Krämer (2015) or van Treeck (2014), which draw much of their inspiration from the works of Piketty (see Piketty 2013). While this literature is still at an early stage and its results can be viewed as preliminary, the models provide valuable insights into some core dynamics and help quantifying the potential self-enforcing character of resource accumulation among a certain share of households in an economy. In particular, the models identify the major economic circumstances that can cause endogenous accumulation.

\footnotetext{
${ }^{1}$ See, for example, Biewen and Juhasz (2012), Schmid and Stein (2013), Corneo (2015) or IAW and ZEW (2015) for an overview of multiple explanations of rising inequality in Germany.
} 
Such models of endogenous accumulation require a sensible empirical calibration for which it is necessary to estimate a whole set of parameters like capital returns, top income and top wealth shares as well as information on the distribution of household savings. However, to date, estimates for most of these parameters can only be regarded as a rough approximation, because they stem from data sources that were not specifically designed for that purpose or have not been available for sensibly recent time periods. One example is the concentration of household savings along the wealth distribution or up to the very top of the income scale.

In this study we provide such estimates for the distribution of household savings along the income and wealth distribution in Germany. In detail, we explore saving amounts, saving rates and shares in total household savings across income and wealth groups for the years 2003, 2008 and 2013. Thereby, we try to shed some light on the concentration of household savings up to the top of the income and wealth distributions and their potential relevance for the evolution of wealth and income inequality. To the best of our knowledge, this has not been done in detail so far.

Our calculations are based on the Sample Survey of Household Income and Expenditure (in German: Einkommens- und Verbrauchsstichprobe - EVS), a large sample containing more than 40,000 households in Germany. ${ }^{2}$ The most recent sample, which provides data for the year 2013, has not been published before spring 2016. These data provide, among others, detailed information on household income, wealth expenditure categories and household savings. The information contained therein can be regarded as of very high quality for a number of reasons. Most prominently, data on household savings are derived from detailed records of incomes and expenditures that sample households are asked to protocol in a so-called housekeeping book during a three-months period. Thus, the usual disadvantages of surveys like memory gaps, framing, etc. are mostly avoided. Moreover, savings do not have to be derived as the difference between income and consumption, which can be considered another source of measurement error.

Our results can be summarized as follows. We find that household savings are highly concentrated along both the income and the wealth distribution. Households in the lower segments of the income and wealth distribution exhibit considerably lower saving amounts, saving rates and shares in aggregate savings compared to households in the upper segments of the distribution. Moreover, the estimated concentration of household savings conditional on the income and wealth distribution steadily increased over the observation period from 2003 until 2013. Finally, our extrapolations of saving rates beyond the EVS's income cut-off of 18.000 euros of monthly household net income ${ }^{3}$ suggest a considerable downward bias in the top income groups' shares in total savings and the total saving rate compared to measures solely based on EVS data.

In the remainder of this paper section 2 briefly summarizes the findings of related studies. In section 3 we introduce the EVS data and describe the construction of the basic variables in detail. Section 4 presents the main results of the analyses. Section 5 addresses the implications of a top income cut-off in the data for the validity of our results at the very top of the income and wealth distribution. Section 6 concludes.

\footnotetext{
${ }^{2}$ In principle, the EVS contains data on about 55,000 households. Yet, the only version of the data that is suitable for our analysis, the so-called Grundfile 3, is an 80 percent subsample of the original data file.

${ }^{3}$ The EVS only comprises households with monthly household net income not exceeding 18,000 euros.
} 


\section{Related literature}

Before laying out the specifics of our data set and discussing our results, we briefly summarize the related literature. Overall, there is only a small number of papers that provide information on the distribution of household savings in Germany.

Brenke and Wagner (2013) report saving rates as well as shares in total household savings across deciles of household net income based on the Socio-economic Panel (SOEP). The sample refers to the years 2001, 2006 and 2011. In the SOEP saving information is available since 1995 and it is possible to track household savings over time in a panel context. However, the survey question underlying the measurement of savings can be seen as an approximation only and allows to collect much less detailed information compared to the EVS. ${ }^{4}$ As a result, the level of household savings is lower in the SOEP and presumably less precise compared to the EVS. Based on the SOEP savings information Brenke and Wagner (2013) document steadily increasing saving rates across income deciles and a considerable concentration of household savings along the income distribution. The average saving rate in the highest income decile amounts to 17 percent, while in the lowest decile it is about 2 percent. Moreover, while the lower half of the distribution makes up for less than 15 percent on total savings, the highest income decile amounts to slightly less than 40 percent of total household savings. ${ }^{5}$

Börsch-Supan et al. (2006) report saving rates and saving amounts across income quartiles derived from SAVE data referring to the year $2005 .{ }^{6}$ These data comprise various categories of retirement schemes and savings to build up wealth-stocks. In principle these data are very well suited to analyze household savings due to the detailed information they provide. However, the representativity of the data is lower compared to the SOEP or the EVS, and the results published so far provide only an overview of the concentration of savings along the income distribution rather than a detailed picture. Based on these data the mean saving rate in the upper income quartile amounts to 18 percent and is significantly higher than in the SOEP, where it lies at approximately 13 percent. ${ }^{7}$

Klär and Slacalek (2006) use EVS data on savings and income for the year 2003. The authors report saving rates across deciles of household income as well as saving rates for the top vingtile and the top percentile. Due to the more comprehensive savings measure in the EVS their results indicate a significantly higher saving rate in the top decile as well as a stronger concentration of savings along the income distribution than in Brenke and Wagner (2013) who use SOEP data.

Our study goes beyond these analyses for various reasons. First, we provide the most recent EVS information which refers to the year 2013. Second, as our calculations are based on EVS data we use very detailed, reliable and representative information to assess the distribution of household savings. Third, we provide three different measures of the savings distribution: saving amounts, saving rates and shares in total household savings. Fourth, we analyze these measures along the income distribution as well as along the wealth distribution. Fifth, we exploit estimates of top income and top

\footnotetext{
${ }^{4}$ See e.g. Fuchs-Schündeln (2008) or Drechsel-Grau and Schmid (2014) for a short discussion of the information that may be deduced from the survey question in the SOEP.

${ }^{5}$ A more detailed comparison with the results of Brenke and Wagner (2013) will be carried out below, when discussing our findings of saving rates and shares in total household savings along the income distribution.

${ }^{6}$ See Coppola and Lamla (2013) for a description of the SAVE dataset.

${ }^{7}$ For SOEP information of mean saving rates across income quartiles see e.g. Behringer et al. (2014).
} 
wealth shares as well as quantiles provided by more specific studies in order to assess the distribution of household savings up to the very top of the income and wealth distribution.

\section{Data and construction of major variables}

For our analysis of household savings, we rely on data from the Sample Survey of Household Income and Expenditure in Germany (in German: Einkommens- und Verbrauchsstichprobe - EVS). The EVS is a large cross-sectional survey of about 40,000 households ${ }^{8}$ conducted by the German Federal Statistical Office. It takes place every five years. The latest wave of the EVS corresponds to the year 2013. Participation in the EVS is voluntary. The survey gathers information about household income, wealth and expenditures. To this aim, the EVS disposes of four different components: a traditional survey part with general information about the household, its members, the housing situation and household endowment with durable goods; a second traditional survey element focusing on wealth; thirdly, a housekeeping book where household members are asked to write down their revenues and expenditures over a three-month period; and finally an even more fine-grained booklet for a detailed recording of expenditures for food, drink and tobacco. Income and wealth, savings and expenditures are collected in great detail. The before-mentioned housekeeping book is of major importance for our analyses, since household savings are deducted from the information provided therein. The survey takes place in several periods across the year in order to rule out seasonal effects.

In the sense of the EVS, households are defined as people who live together and share their incomes and expenditures (Destatis 2008, p. 6, own translation). Part of the survey are all households at their principle domiciles. Persons who are permanently absent or live in the household only for a small part of the week, e.g. students, are not considered part of the household. (Rather, they form a household of their own if interviewed.) Among others, the homeless or people in communal accommodation are not part of the survey. Importantly, households with a monthly net income of more than 18,000 euros are not part of survey either (Destatis 2008). Since high incomes tend to go together with high wealth, an underestimation of households with high wealth is also very likely. This should be borne in mind when interpreting our results (see also section 5 for a more detailed discussion).

The EVS is organized as a non-probabilistic quota sample. The type of the household, the social standing of the person with the highest income in the household, and the monthly net household income serve as variables to build the quotation cells. To insure representativity, the EVS data are weighted and calibrated according to the Mikrozensus, a large yearly random sample of 1 percent of the German households, where participation is obligatory. Of course, since participation in the EVS is voluntary, some selection issues cannot be completely ruled out. Known aspects involve the underrepresentation of people aged 80 years or more, households with non-German household heads and people with a low degree of schooling and professional education. Vice versa, people with a high degree of schooling and high professional education are overrepresented in the EVS. Poor people, however, do not seem to be underestimated in the EVS, as household income is used to construct the quotation cells and households are weighted according to the Mikrozensus. Furthermore, the quota

\footnotetext{
${ }^{8}$ We use the so-called Grundfile 3 for our analyses which represents an 80 percent subsample of the original datafile.
} 
sample design includes the active recruitment of poor households, inter alia, by reverting to social assistance offices or debt advice services.

With regard to the major variables used for our analyses, household gross income includes earnings from dependent and self-employed labor, public and non-public transfers (both regular and irregular), income on investments, and income on sublets; household net income furthermore includes grants by the employer, income on the selling of goods and other incomes, but deductions from household income have to be subtracted. All of these variables stem from the housekeeping book and are thus very reliable. Labor earnings are collected at the individual level and include special payments in case of dependent employees $\left(13^{\text {th }}\right.$ and $14^{\text {th }}$ salary, holiday pay)..$^{9}$ It shall not be concealed, that measuring self-employed people's income is somewhat more problematic. Destatis $(2008$, p. 39) notes that labor earnings of the self-employed are much lower in the EVS than in the National Accounts System or in the European Union Statistics of Income and Living Conditions (EU-SILC). While this seems to be a common problem of voluntary surveys and is in no case specific about the EVS, it should be borne in mind when interpreting our results.

Household net wealth includes monetary assets and real assets, as well as household debt. Household savings notably are not constructed as the difference between income and consumption; rather, the following positions that all stem from the housekeeping book and can therefore be considered very reliable are taken into account: expenditures for the building of tangible assets; redemption of credits; income from the conversion of tangible and intangible assets; income from borrowing; and, finally, interest payments for credits borrowed.

Especially the savings information contained in the EVS is of very high quality and lies at the heart of our analysis. It goes far beyond usual survey questions, which are prone to measurement error due to memory gaps or respondents not taking into account not-so-obvious savings positions like payments to pension plans, interest payments or the redemption of credits. The fact that most of the information which is necessary for our contribution stems from the housekeeping book makes the EVS the bestsuited data set for our analyses of the distribution of household savings in Germany.

\section{Results}

In the following section we present our basic results. First, we analyze saving amounts, saving rates and shares in total household savings across different income groups. ${ }^{10}$ Afterwards we illustrate the distribution of these measures across groups of household net wealth. In the main text, we focus on the year 2013. The corresponding results for the years 2003 and 2008 are reported in Table 5 to Table 6 and in Figure 8 and Figure 9 in the Appendix. Confidence intervals for the estimated savings amounts and saving rates are reported in Table 7 to Table 10 in the Appendix.

\footnotetext{
${ }^{9}$ Note that employers' payments to the social security system are not part of the labor earnings variable.

10 Throughout this paper we generally refer to top income groups when using the terms decile, vingtile or percentile, except in Table 1 and the lower part of Table 2, where we refer to the lower borders of the respective income groups' income ranges.
} 


\subsection{Household savings across the income distribution}

Figure 1 shows average deflated saving amounts along the distribution of household net income for 2013 (base year of deflation is 2013). ${ }^{11}$ Depicted are the first nine income decile classes, the 91st to 95th and 96th to 99th percentile classes as well as the top percentile class.

Figure 1: Yearly saving amounts across income groups (2013)

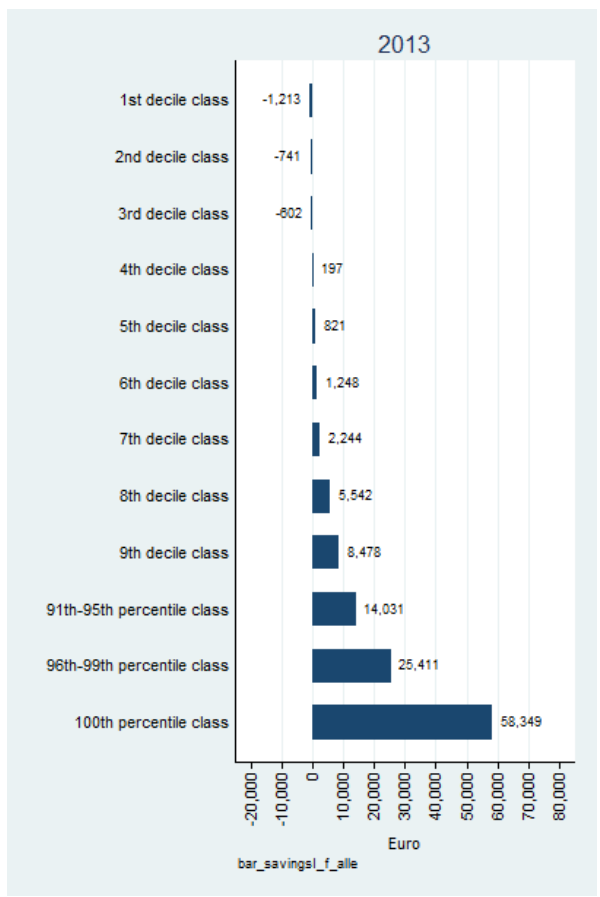

Source: EVS, own calculations. Calculations based on 2013 euros.

Saving amounts steadily increase across the income distribution. The first three decile classes feature negative household savings, i.e. at least on average these households consume more than they earn. Note that this does not necessarily mean that every household among those 30 percent of households with the lowest net incomes runs into debt, since there is also a considerable intra-class variation of savings. Decile classes four and five save an average of less than 100 euros per month. The 6 th decile approximately saves 100 euros per month. Above the 9 th decile class household savings exceed 1,000 euros per month (approximately 14,000 euros per year). Above the 19th vingtile class the average saving amount exceeds 2,000 euros per month (slightly more than 25,000 euros per year). The top percentile group saves an average of nearly 5,000 euros per month (see Table 7 in the Appendix for the corresponding confidence intervals).

A comparison of these results to the years 2003 and 2008 (see Table 5 in the Appendix) reveals that average savings declined for income deciles one through eight, with the decline being less pronounced, the higher the income position of a household is. For example, mean savings of the fourth income

\footnotetext{
${ }^{11}$ Since one purpose of this paper is to provide parameters for macro models of endogenous accumulation we report (weighted) arithmetic means throughout our analyses instead of the median.
} 
decile class have dropped by about 70 percent between 2003 and 2013, while the corresponding decrease for the eighth decile class amounts to less than -10 percent. For households in the ninth and tenth income decile class, the change in savings turns positive, the exception being the top percentile class whose average savings have declined by about 13 percent.

Next we analyze saving rates conditional on the distribution of household net income. Again, we consider decile groups one to nine and split the top decile class into percentiles 91 to 95,96 to 99 and the top percentile group. Figure 2 summarizes the results for the year 2013. Table 6 in the Appendix reports results for the years 2003 and 2008.

Figure 2: Saving rates across income groups (2013)

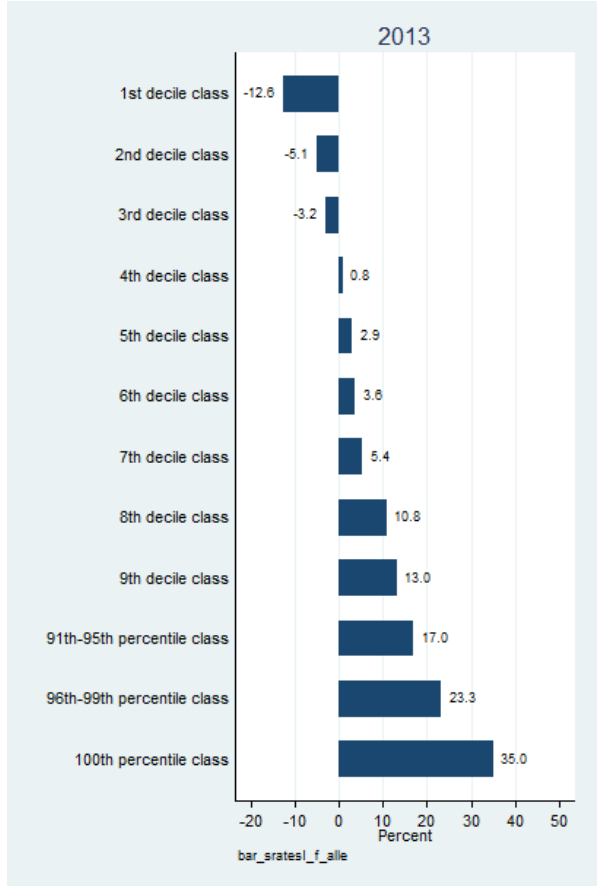

Source: EVS, own calculations. Calculations based on 2013 euros

In 2013 the average saving rate steadily increases across the income distribution. Hence, not only average saving amounts are positively associated with higher income but also savings as a share of household net income increase with higher incomes. Thus, not only households' saving amounts but also their inclination to save rises with their income.

Corresponding to the negative saving amounts reported above, for the first three decile classes' saving rates are reported as negative values. Through decile groups four to seven saving rates are comparably low, ranging from 0.8 to 5.4 percent. Income deciles eight and nine show considerably higher saving rates that lie above 10 percent. For the percentile groups 91 to 95 the average saving rate amounts to about 17 percent. For the percentile groups 96 to 99 the average saving rates are close to one fourth of household net income. The top percentile's average saving rate is still substantially higher, amounting to 35 percent. 
These findings are very similar to the saving rates reported by Klär and Slacalek (2006). Moreover, the pattern is in line with the SOEP saving rates reported by Brenke and Wagner (2013). There, saving rates also increase monotonously across income deciles, and a clear jump between the 9th income decile and the top income decile can be observed. In case of the EVS data, the top income decile's saving rate in 2013 amounts to about 22.6 percent, which is - as expected - somewhat higher than its SOEP counterpart (17 percent).

For the years 2003 and 2008 (see Table 6 in the Appendix) this pattern is very similar, and saving rates increase monotonously with household net income. The top percentile group in these years is close to 40 percent and is thus even higher than in 2013. Over the years 2003 to 2013, saving rates declined in almost every income class, the decrease being more pronounced in the lower income groups.

We complete our analysis of savings along the income distribution by considering the conditional distribution of shares in total household savings given household net income. This serves as an indicator for the concentration of household savings. Figure 3 illustrates the corresponding results for the year 2013. Figure 8 in the Appendix adds the respective results for the years 2003 and 2008.

Figure 3: Shares in total savings across income groups (2013)

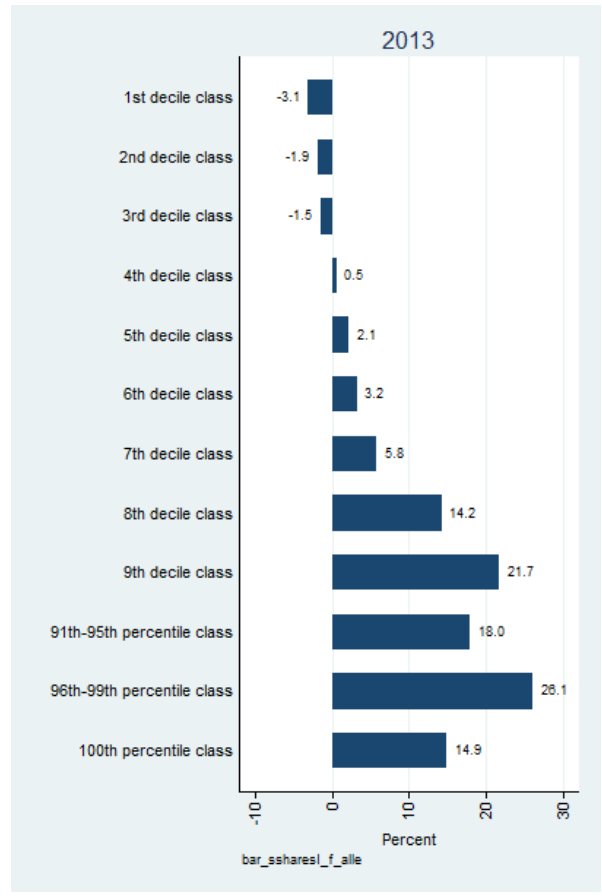

Source: EVS, own calculations. Calculations based on 2013 euros.

Household savings are highly concentrated across the income distribution. In 2013, the top income decile accounts for roughly 58 percent of total household savings. Based on SOEP data according to Brenke and Wagner (2013) the top income decile's share in total savings is between 35 and 40 percent, on the contrary. Yet, this result is not surprising as the savings information in levels between the EVS and the SOEP is not directly comparable (see above). The upper 20 percent of the income distribution 
account for about 80 percent of total household savings in 2013. The upper income vingtile makes up about 40 percent and the top income percentile about 15 percent of total household savings.

When comparing these findings to the years 2003 and 2008, we see that while the share of the top income percentile class is practically stable at approximately 15 percent, the share of percentiles 91 to 99 increases by about 8 percentage points. Both mean saving rates and mean savings increased somewhat for this income group (and in particular for the 96th to 99th percentile class), and so did their corresponding sums of savings. Yet, at the same time total savings in the economy declined considerably between 2003 and 2013 (from about 171 to 153 billion euros corresponding to a relative change of about -10.6 percent). As a result, the share in savings for this income class increased. On the contrary, in the top income percentile group mean savings (and mean saving rates) declined substantially. But their decline was roughly proportional to the change in total savings in the economy. As a consequence, their share in total savings remained quite constant over the years.

\subsection{Household savings across the wealth distribution}

In this subsection we take a look at the savings distribution across groups of household net wealth. Analogously to the previous analyses we classify household net wealth in ten deciles, where the highest decile is split into a $91^{\text {st }}$ to $95^{\text {th }}$ percentile class, a class containing households belonging to the $96^{\text {th }}$ to $99^{\text {th }}$ percentiles as well as a group for the top 1 percent of wealth owners in Germany.

In principle we would expect a similar pattern in the conditional distribution of household savings as observed for the income distribution: rising saving amounts and saving rates across wealth groups. This is because relative positions within the income and wealth distribution are positively associated. Actually, there are only very few relatively wealthy households that earn comparably little incomes. Out of all households belonging to the highest wealth decile, less than 10 percent belong to the lower half within the income distribution (see Table 11 in the Appendix). Likewise, only few households belonging to the lower half of the wealth distribution can be found in the higher income decile classes.

Figure 4 summarizes wealth group-specific average saving amounts for the year 2013. Table 5 and Table 8 in the Appendix provide a representation for the years 2003 and 2008 and the corresponding confidence intervals. Indeed, savings rise (again) monotonously along the wealth scale, with the exception of the first wealth decile class which exhibits relatively high savings compared to the other wealth decile classes in the lower half of the wealth distribution. The reason for this is the comparably high share of mid and high income households in the first wealth decile compared to wealth deciles two to four. While mean savings amount to about 1,290 and 2,450 euros per year in the fourth and fifth wealth decile class, respectively, in wealth decile classes seven to nine average annual savings exceed 5,000 euros. Within the wealth group comprising percentiles 91 to 95 the average annual savings amount is slightly below 9,000 euros. For wealth percentiles 96 to 99 it is approximately 11,700 euros per year. In the top wealth percentile group average household savings amount to about 24,000 euros per year, i.e. 2,000 euros per month. In general, saving amounts are considerably lower compared to those in the corresponding income classes. The difference in absolute terms is more pronounced for the higher wealth classes. In relative terms, though, the opposite holds. 
Figure 4: Saving amounts across wealth groups (2013)

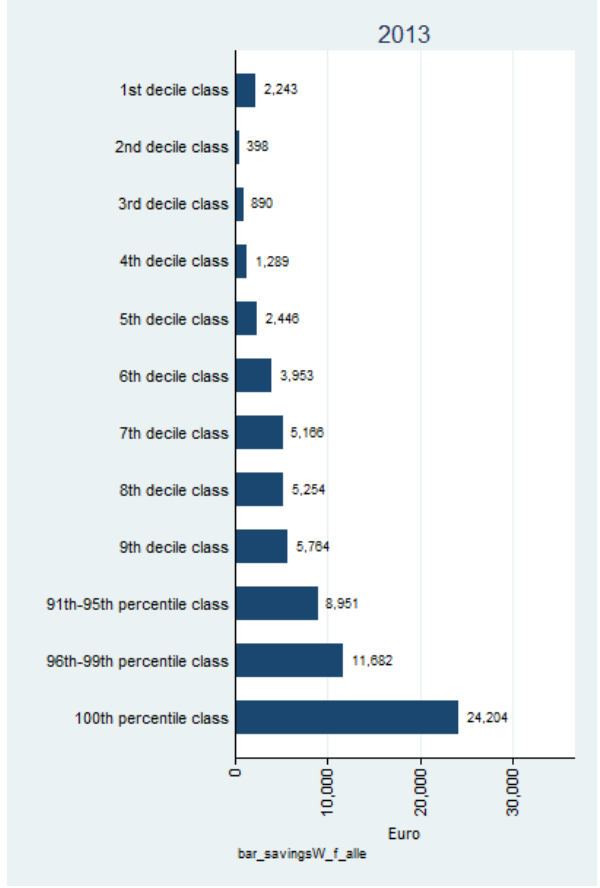

Source: EVS, own calculations. Calculations based on 2013 euros.

For the years 2003 and 2008 the general pattern is quite similar, i.e. saving amounts rise steadily from the second wealth decile onwards. At the upper end of the distribution, the top percentile indicates much higher savings than the 96th to 99th percentile class. Yet, these results have to be treated with caution as the statistical uncertainty is quite high at that part of the distribution - see the confidence intervals in Table 8 for a better assessment of the issue. Between 2003 and 2013 savings have declined substantially for almost every wealth class. This drop in savings is particularly high for the lower half of the wealth distribution and keeps getting less pronounced for higher wealth classes. Only for the first wealth decile class and the top percentile group of wealth owners, savings have risen by about 26 and 5 percent, respectively. Again, see the confidence intervals in Table 8 for a better understanding of the statistical uncertainty involved in these results.

Due to the less concentrated saving amounts across the wealth distribution compared to the analyses along the income scale, the level of saving rates is also considerably lower in the upper part of the distribution and higher in the lower wealth groups, see Figure 5). For example, the top wealth percentile saving rate amounts to one fourth of household net income, while the saving rate for the top income percentile class lies at about 35 percent in 2013. Moreover, while the first income decile class exhibits negative savings and saving rates, the lowest wealth decile class saves an average of about 8 percent of net household income. For the years 2003 and 2008 we observe a similar pattern (see Table 8).

Finally, Figure 6 reports wealth group-specific shares in total household savings for the year 2013 (see Figure 9 in the Appendix for results for the years 2003 and 2008). Again, it becomes apparent that the concentration of savings is lower compared to the analyses across the income distribution. But still, the share in aggregate savings of the upper percentile classes is considerably higher than the shares of 
the lower wealth groups. For example, the top wealth decile accounts for more than 30 percent of aggregate savings, while the lower half of the wealth distribution only makes up of 18.7 percent which is comparable to the top vingtile group's share in savings (18.2 percent).

Figure 5: Saving rates across wealth groups (2013)

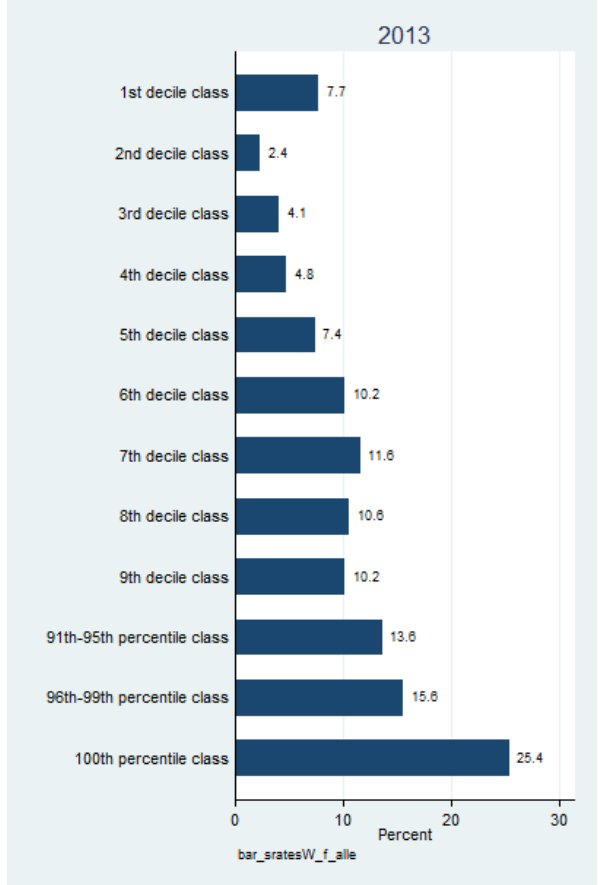

Source: EVS, own calculations. Calculations based on 2013 euros.

Figure 6: Shares on total savings across wealth groups (2013)

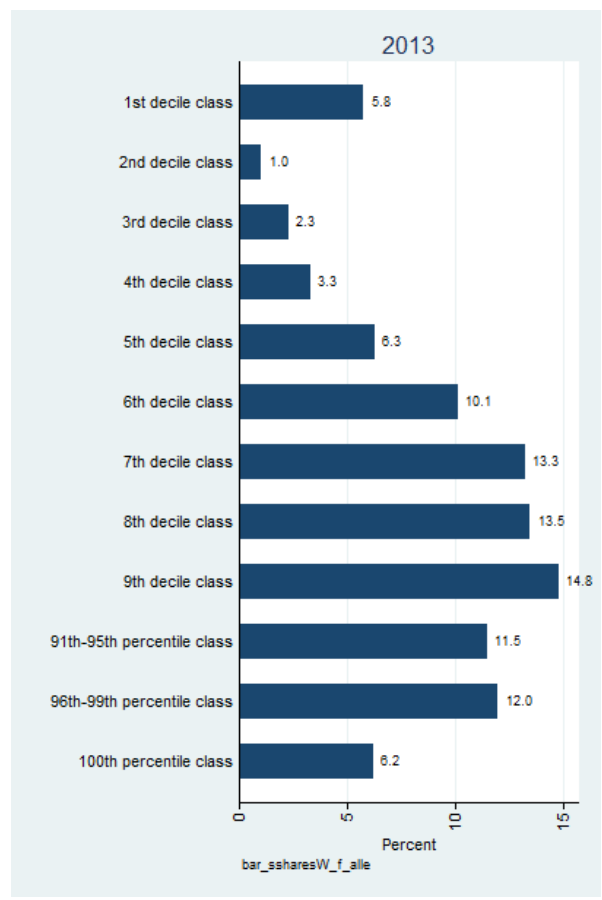

Source: EVS, own calculations. Calculations based on 2013 euros. 
For the years 2003 and 2008 the results are similar, although we observe a small and steady increase in the distribution of saving shares across wealth groups over the years. While in 2003 the share in total household savings of the top wealth decile amounted to 27.1 percent, it lies at about 29.7 percent in 2013. The share for the lower half of the wealth distribution (deciles one trough five) fell from 20.6 percent in 2003 to 18.7 percent in 2013.

\section{Implications of the high-income cut-off in the EVS}

In general, our estimates of household savings can be considered as of very high quality due to the characteristics of the EVS sample (see section 3 for details). However, as already mentioned, the EVS underlies a high income cut-off threshold. According to this, households with monthly net incomes higher than 18,000 euros are excluded from the sample due to low expected response rates. This selection issue cannot be cured by weighting and calibrating the sample and induces biases in the estimates of all of our measures for the distribution of household savings. The reason is that top income households are likely to be among the top saving households, too. Hence, an important question is how large the potential bias of our saving estimates might be. To address this issue, we use this section for an educated guess, since only little is known about the distribution of top incomes beyond the 18,000 euros income threshold. In the following we exploit findings of the existing literature to find out more about this issue.

Independent from the uncertainty associated with the results in the literature, though, we may already state that the skewness of the distributions of savings, saving rates and shares in total savings across income and wealth decile groups should play a crucial role in this context. ${ }^{12}$ The more right-skewed they are, the more pronounced should be the bias stemming from the lack of top income households - at least if one assumes that the skewness continues into the unknown part on the right-hand side of the distributions and that households beyond the income threshold make up for savings, saving rates and shares in total savings that exceed those of the top income households that can be observed. However, this does not seem not too unlikely to be the case, in our eyes.

Moreover, at a given skewness of the distribution of our measures of savings across income (and wealth) deciles, we would furthermore expect the bias to be less severe for saving amounts and saving rates, compared to shares in total savings. This is because in the case of new information on top income households being revealed, the income and wealth decile classes' frontiers would shift downwards compared to the above calculations, depending on how many new observations become available in the upper part of the tail. Since observable savings and saving rates rise monotonously with income and wealth, our estimates should thus suffer a certain upward bias for all income and wealth decile classes but the very top classes: In the top percentile class, for example, the new observations would induce higher estimates of savings and the saving rate. ${ }^{13}$ Note, however, that the income level of these new households would not matter in this context for all classes except the top percentile class. That is,

\footnotetext{
${ }^{12}$ This issue is closely related to the assessment of top wealth shares. For a more detailed analysis of the skewness of the wealth distribution and top wealth shares see Davies et al (2010) and Davies and Shorrocks (1999).

${ }^{13}$ Of course, aggregate savings and the aggregate saving rate are downward biased when households beyond the 18,000 euros threshold are excluded.
} 
unless an overwhelming quantity of households beyond the 18,000 euros threshold became available, we would not expect savings and saving rates for the lower 99 percent of households normally observable in the EVS to underlie dramatic changes. ${ }^{14}$ Looking at shares in total savings by decile classes, however, the income level of the newly observable households beyond the threshold is relevant, too. The higher their share in total household savings, the higher will be the upward bias in our estimates of the income and wealth decile groups' shares in aggregate savings. Again, the exception being the groups at the very top. Their shares in aggregate savings are underestimated with the EVS data when households beyond the 18,000 euros threshold cannot be observed.

In what follows we address this bias in the concentration of household savings in three steps. First, we assess the gap between the EVS sample underlying our analysis and datasets that provide much more detailed information on the top of the income and wealth distributions. In the second step, we fit a simple regression model in order to extrapolate conditional corrected saving rates given a set of assumptions. Finally, we match the extrapolation with the presumably more adequate income levels at the top of the income distribution to provide some insight into the potential size of the bias of the aggregate saving rate and the bias of the top income groups' shares in total savings. ${ }^{15}$

\subsection{Implications on the distribution of household income}

To assess the extent of the lack of information at the top of the income distribution, we compare income percentiles and top income shares of the income distribution calculated from the EVS with results based on integrated data sources that actually do cover the top tail of the distribution. To this end, we refer to the results presented in Bach et al. (2016). These authors construct two integrated databases that match EVS and SOEP income data as well as EVS, SOEP and income tax data. In particular, taking administrative tax data into account allows for a more comprehensive coverage of capital income and a much better approximation of the top of the income distribution (see also Bach et al. 2009, Bartels and Jenderny 2014 or Schmid et al. 2015).

Bach et al. (2016) report income shares, average income levels of top income groups as well as percentiles based on net equivalized and gross equivalized household income across the distribution of gross equivalized household income. As our results presented so far refer to household net income and neither to gross income nor equivalized income measures, we cannot directly compare the income distribution underlying our analysis of household savings with Bach et al. (2016). Hence, we construct the corresponding information, i.e. gross equivalized income and net equivalized income, for the EVS sample and contrast the outcome with the findings of the integrated data sources. Table 1 presents the results of this step.

\footnotetext{
${ }^{14}$ This is consistent with the estimates in Bach et al. (2015), see Table 7. There, percentiles up to the top $1 \%$ of household net wealth are not changed by including an imputed top of the wealth distribution. Only from the top $0.5 \%$ upwards percentile values are changed due to the imputation.

${ }^{15}$ Although also of high importance, for the sake of brevity and because of the high statistical uncertainty that might be involved, we do not extrapolate into the upper tail of the wealth distribution and leave this issue to further research.
} 
Table 1: Comparison of top income shares and income quantiles across different data sources

$\underline{\operatorname{EVS}(2008)^{*}}$

\begin{tabular}{lcccc}
\hline \multirow{2}{*}{$\begin{array}{l}\text { Groups of gross } \\
\text { equivalized income }\end{array}$} & \multicolumn{3}{c}{ Gross equiv. income } & Net equiv. income \\
\cline { 2 - 5 } & share & group mean & percentile & share \\
\hline Top 1 \% & $4.5 \%$ & 11,211 & 8,604 & $4.0 \%$ \\
Top 5 \% & $15.2 \%$ & 7,549 & 5,558 & $13.9 \%$ \\
Top 10\% & $25.1 \%$ & 6,246 & 4,472 & $23.2 \%$ \\
\hline
\end{tabular}

Integrated SOEP/EVS-database (2008)**

\begin{tabular}{|c|c|c|c|c|c|}
\hline \multirow{2}{*}{$\begin{array}{l}\text { Groups of gross } \\
\text { equivalized income }\end{array}$} & \multicolumn{4}{|c|}{ Gross equiv. income } & \multirow{2}{*}{$\begin{array}{c}\text { Net equiv. income } \\
\text { share }\end{array}$} \\
\hline & share (1) & share (2) & group mean & percentile & \\
\hline Top 1 \% & $5.6 \%$ & $5.5 \%$ & 14,780 & 9,419 & $5.0 \%$ \\
\hline Top $5 \%$ & $16.4 \%$ & $16.2 \%$ & 8,676 & 5,916 & $13.8 \%$ \\
\hline Top $10 \%$ & $26.4 \%$ & $26.1 \%$ & 6,991 & 4,869 & $22.3 \%$ \\
\hline
\end{tabular}

$\underline{\text { Integrated SOEP/EVS/IncomeTax-database (2008) }}{ }^{* *}$

\begin{tabular}{|c|c|c|c|c|c|}
\hline \multirow{2}{*}{$\begin{array}{l}\text { Groups of gross } \\
\text { equivalized income }\end{array}$} & \multicolumn{4}{|c|}{ Gross equiv. income } & \multirow{2}{*}{$\begin{array}{c}\text { Net equiv. income } \\
\text { share }\end{array}$} \\
\hline & share (1) & share (2) & group mean & percentile & \\
\hline Top $1 \%$ & $10.8 \%$ & $11.0 \%$ & 30,287 & 11,116 & $10.0 \%$ \\
\hline Top $5 \%$ & $21.6 \%$ & - & 12,138 & 6,001 & - \\
\hline Top $10 \%$ & $29.9 \%$ & $30.6 \%$ & 8,406 & 4,699 & $28.0 \%$ \\
\hline
\end{tabular}

\footnotetext{
* Source: EVS, own calculations. Calculations based on monthly equivalized net household incomes in 2008 euros.

** Source: Bach et al. (2016) and own calculations.

Note: The upper panel features our own calculations based on EVS data for the year 2008. The centered and lower panels summarize top income information based on integrated data sources as presented by Bach et al. (2016) and own calculations. All calculations are based on 2008 euros. We contrast the distribution of net and gross equivalized income within top income groups of gross equivalized income across different data sources. The representation is limited by the availability of information from Bach et al. (2016). This means for example, that we do not report group-specific averages of net equivalized income as Bach et al. (2016) do not provide this information. The intervals of the shares for gross equivalized income (share 1 and share 2) from Bach et al. (2016) result from different approximation methods of the underlying data.
}

In the upper panel we summarize the information based on EVS data only. The centered panel refers to integrated data of EVS and SOEP. The lower panel corresponds to the integrated database that also covers information from tax return data. We see that based on the integrated data that combines SOEP and EVS information the top income groups reveal higher average income levels and hence the corresponding income shares exceed the shares calculated based on EVS data alone. As the information from the SOEP adds households at the top of the income scale, the rise in group-specific means is particularly substantial in the top percentile group. Regarding gross equivalized income the gap amounts to approximately 3,500 euros per month. For the top decile class this gap is approximately 800 euros. While this first comparison already indicates the limitations of the EVS's high income cutoff, the gap becomes even more apparent when we consider the integrated data that include tax 
return information. Here the level of the top percentile group's average monthly gross equivalized income amounts to about 30,000 euros indicating a monthly gap of more than 19,000 euros (before taxes and social security contributions) compared to EVS data alone.

These differences translate into a considerable wedge between the income shares of the different data sources. As a simple approximation we can say that in the integrated data base including tax data the income shares of the top percentile class lie about 6 percentage points above their EVS counterparts (5 percent in the EVS versus 11 percent in the integrated database). The top decile groups' income shares exceed the EVS measures by 1 and 5 percentage points, respectively ( 25 percent in the EVS versus 26 percent with EVS and SOEP data versus 30 percent in the integrated database including tax data).

We do not observe considerable differences between the evaluation based on gross equivalized income compared to net equivalized income. Moreover, the income shares are very similar compared to those based on household net income as used in our savings analysis, in which the top percentile group's income share is 4.3 percent and the top decile's income share is 25.9 percent for the year 2008 (see Figure 10 in the Appendix).

\subsection{Implications on the distribution of household wealth}

Due to the high income cut-off not only very high income households but also top wealth households are missing from the data. To assess the gap stemming from missing high income households at the top of the wealth distribution we compare shares on total household wealth in the EVS to shares estimated from different data sources as provided in the literature.

Therefore, we refer to the studies by Vermeulen (2014), Westermeier and Grabka (2015) as well as Bach et al. (2015). These studies estimate Pareto distributions to assess wealth percentiles and wealth shares up to the top of the distribution of household net wealth. We refer to these analyses as the authors consider different data sources, namely HFCS data, SOEP data as well as rich list information from Forbes and the manager magazin.

The upper part of Table 2 contrasts top wealth shares from the EVS with respective estimates drawn from Pareto estimations building on HFCS or SOEP data including rich list information. While the estimates of top wealth shares yield comparably similar results across these studies - about one third of total household net wealth corresponds to the top percentile class and 50 percent of total wealth corresponds to the top wealth vingtile group - we observe considerable differences to the EVS estimates. In the EVS population the top wealth percentile group's share in total household net wealth amounts to between twelve and 13 percent. The top wealth vingtile group in the EVS holds only about one third of total household net wealth.

Likewise, the considerable difference between the EVS estimates and the estimates from combined data sources from the literature is also reflected in the size of the percentiles (here denoting the lower border of the respective income group's income range) of household net wealth (depicted in the lower panel of Table 2). In addition to the income levels from the combined data sources estimates from HFCS and SOEP data without corrections are also included. 
Table 2: Comparison of top wealth shares across different data sources

Shares in total net household wealth (in percent)

\begin{tabular}{lccccc} 
& EVS (2008) & EVS (2013) & HFCS/Forbes (2010/11)* & SOEP/Forbes (2012)** & HFCS/manager magazin (2010/11)*** \\
\hline Top 1 $\%$ & 13 & 12 & $24-33$ & $31-34$ & 32.7 \\
Top 5 $\%$ & 35 & 33 & $51-53$ & $52-57$ & 51.7 \\
Top 10\% & 51 & 50 & - & $63-74$ & 63.7 \\
\hline
\end{tabular}

* Source: Vermeulen (2014); Pareto estimations based on HFCS and Forbes data corresponding to the years 2010/11. The reported intervals reflect to the range of estimation results stemming from different parameterizations and the consideration of rich list data.

** Source: Westermeier and Grabka (2015); Pareto estimations based on SOEP and Forbes data referring to the year 2012. The reported intervals reflect the uncertainty in the estimation results.

*** Source: Bach et al. (2015); HFCS and manager magazin data including imputed top wealth distribution corresponding to the years $2010 / 11$.

Percentiles of net household wealth

\begin{tabular}{lcccccc} 
& EVS (2008) & EVS (2013) & HFCS (2010/11)** & SOEP $(2012)^{* *}$ & HFCS/Forbes $(2010 / 11)^{*}$ & HFCS/manager magazin $(2011) * * *$ \\
\hline Top 1 \% & $1,091,594$ & $1,029,612$ & $1,929,344$ & $1,349,640$ & $1,930,000-2,200,000$ & $1,887,000$ \\
Top 5 $\%$ & 519,727 & 522,569 & 661,240 & 563,100 & $660,000-710,000$ & 668,000 \\
Top 10 $\%$ & 355,796 & 357,582 & 442,320 & 380,740 & - & 438,000 \\
\hline
\end{tabular}

* Source: Vermeulen (2014); Pareto estimations based on HFCS and Forbes data corresponding to the years 2010/11. The reported intervals reflect to the range of estimation results stemming from different parameterizations and the consideration of rich list data.

** Source: Westermeier and Grabka (2015).

*** Source: Bach et al. (2015); HFCS and manager magazin data including imputed top wealth distribution corresponding to the years $2010 / 11$.

Source: EVS, own calculations. Calculations based on 2008 and 2013 euros.

\subsection{Implications for the distribution of household savings}

The comparisons above show that within our data the top of the income and wealth distribution appears to be heavily underrepresented. As a result, savings, saving rates and shares in aggregate savings are underestimated. This applies particularly to the top income (and wealth) groups where the impact of observations beyond the 18,000 euros income threshold in the EVS is especially pronounced (see above for a more detailed view on this aspect). Likewise, aggregate savings and the aggregate saving rate are underestimated using EVS data alone.

To assess how large the bias of our estimates might be, we run a simple regression model of the savings rate conditional on a polynomial of third order of household net income. Besides a constant, no other variables are taken into account. Thus, this purely descriptive exercise must not be interpreted as a rock-solid estimate of the 'effect' of income on the saving rate.

Figure 7 shows saving rates along the income scale as predicted by the regression model. The shaded area indicates the frontiers of a 95 percent confidence interval. Clearly, the higher the income, the higher the statistical uncertainty associated with the estimates of saving rates. The red vertical line indicates the 18,000 euros income threshold in the EVS. Beyond this point, Figure 7 also contains an out-of-sample prediction of saving rates for households with larger net monthly incomes. Yet, particularly for these out-of-sample predictions the confidence intervals are quite large so that the utmost care has to be taken when gauging saving rates for these households. Also, the assumption that the mechanics of the regression model (which was fit for households with net monthly incomes of less than 18,000 euros) also hold beyond this cut-off cannot be verified. 
Referring to our initial question of how large the bias in our estimates of saving rates for several income and wealth groups might be, Figure 7 gives some indication about what can be hypothesized. Apart from the points on the $x$-coordinate that increase in steps of 500 euros, Figure 7 also contains predicted saving rates at the corrected average income levels of the top 10, top 5 and top 1 percent of households according to net household income. To that aim, we calculated their respective average levels of gross equivalized income based on EVS data in a first step. In a second step we calculated the relative differences between EVS values for those top income groups and the corresponding numbers of the integrated data sources described in section 5.1. Thirdly, we applied these factors to the top income groups' average net income levels as calculated from the EVS in order to attain 'corrected' average income levels for the top income groups. Finally, we evaluated our estimated regression function at these corrected income levels in order to attain corrected saving rates.

Figure 7: Predicted saving rates

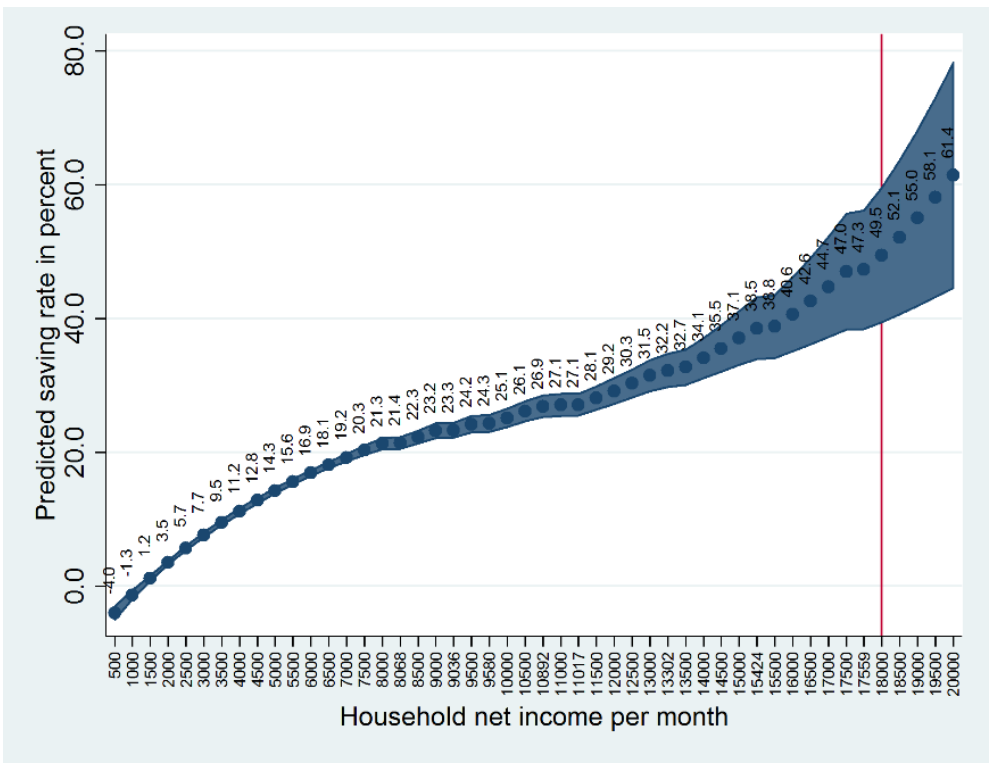

Source: EVS, 2008, own calculations. All calculations based on 2013 euros.

Table 3 summarizes the results. We compare predicted saving rates based on EVS data alone to predictions based on average incomes as suggested by the values of the integrated data bases such as EVS and SOEP (column two) and EVS, SOEP and tax data (column three) as described in section 5.1.

The predicted saving rate for the top 10 percent of households along the income scale based on EVS data alone amounts to about 21.4 percent (which corresponds to evaluating the regression function at the group's average income of 8,068 euros). Performing the same calculation based on EVS and SOEP data according to the procedure described above leads to a higher saving rate of about 23 percent. According to EVS, SOEP and tax data the procedure leads to a predicted saving rate of nearly 27 percent. Thus, if all assumptions involved in these calculations were correct, the saving rate of the top income decile would suffer from substantial underestimation of about 5 and 10 percentage points, respectively. Results for the top 5 and top 1 percent of income households point to an even heavier underestimation when using EVS data alone. 
Table 3: Corrected and uncorrected predicted saving rates for the top 10, 5 and 1 percent of households according to net household income, 2008

\begin{tabular}{lccc}
\hline Predicted saving rates & EVS & EVS and SOEP & EVS, SOEP and tax data \\
\hline \multirow{2}{*}{ Top $10 \%$} & $21.4 \%$ & $23.3 \%$ & $26.9 \%$ \\
& {$[20.6 ; 22.3]$} & {$[22.2 ; 24.4]$} & {$[25.3 ; 28.5]$} \\
& $(8,068$ euros $)$ & $(9,036$ euros $)$ & $(10,892$ euros $)$ \\
\hline \multirow{2}{*}{ Top $5 \%$} & $24.3 \%$ & $27.1 \%$ & $38.5 \%$ \\
& {$[23.1 ; 25.6]$} & {$[25.5 ; 28.7]$} & {$[33.9 ; 43.1]$} \\
& $(9,580$ euros $)$ & $(11,017$ euros $)$ & $(15,424$ euros $)$ \\
\hline \multirow{2}{*}{ Top $1 \%$} & $32.2 \%$ & $47.3 \%$ & n.a. \\
& {$[29.7 ; 34.7]$} & {$[38.4 ; 56.1]$} & [n.a.] \\
& $(13,302$ euros $)$ & $(17,559$ euros $)$ & $(35,915$ euros $)$ \\
\hline
\end{tabular}

Source: EVS, 2008, own calculations. All calculations based on 2013 euros. 95 percent confidence intervals in brackets. Values of household net monthly income were used for the prediction of saving rates correspond to the average income in those groups and are shown in parentheses. The predicted saving rate for the top percentile according to EVS, SOEP and tax data cannot be sensibly calculated as the statistical uncertainty is way too high at such high values of income.

To approximate the size of the potential downward bias in estimates of the aggregate saving rate and the concentration of household savings we further refine the results in Table 3 by simulating the effects of an increase in the income shares and average saving rates of the top income decile class and the top income percentile class. The simulation is shown in Table 4. The upper part refers to the top decile class, while the lower part summarizes the results for the top percentile class.

We illustrate the potential changes to the top income group's share in total savings and the potential change of the aggregate saving rate in three steps. Again, all calculations are carried out for the year 2008 to ease comparability of the EVS data with the two integrated data sources. The benchmark scenario is the EVS, which is summarized in columns (1) and (2) in Table 4. The top decile group's income share as calculated from the EVS denotes 25.9 percent (column2, row A). The top decile's saving rate is set to the predicted saving rate at the average class income (21.4 percent, see Table 3 and column 2, row B in Table 4), and the saving rate of the remaining population as calculated from the EVS amounts to 6.5 percent (column 1, row B). This calibration leads to an aggregate saving rate of 10.4 percent (row $\mathrm{H}$ ) and a share in total savings of about 54 percent for the top decile class (column 2 , row $\mathrm{G}$ ). These values correspond closely to what can be directly observed in the EVS data. Here, the top decile group's share in savings lies at 56 percent and the aggregate saving rate amounts to about 11 percent. $^{16}$

In the first step, we increase the top decile group's income share to 31.3 percent (column 4, row A), which corresponds to our approximated top decile group's income share from the integrated EVS, SOEP and Tax database. Consequently, the income share of the lower 90 percent of households decreases to about 69 percent (column 3, row A). All other exogenous model parameters remain

\footnotetext{
${ }^{16}$ Note that we attain this difference as (for consistency reasons) we apply the predicted saving rate at the class mean rather than the actual mean saving rate of the class in the model. When calibrating the application with the actual data we can replicate the exact sample values of aggregate savings rates as well as shares in total savings.
} 
unchanged. As a result of the higher income share of the top decile class, its saving amount increases and its share in aggregate savings rises by about 6 percentage points, from 54 to about 60 percent (column 4, row G). Since the aggregate savings amount has increased (columns 3 and 4, row F), the aggregate saving rate rises by almost one percentage point, from 10.4 to about 11.2 percent (columns 3 and 4 , row $\mathrm{H}$ ).

Table 4: Simulation of the effect of the availability of data on households beyond the 18,000 euros threshold in the EVS on shares in total household savings and the aggregate saving rate

Top decile group

\begin{tabular}{|c|c|c|c|c|c|c|c|c|c|}
\hline & & \multicolumn{2}{|c|}{ EVS 2008} & \multicolumn{2}{|c|}{$\Delta$ Top income share } & \multicolumn{2}{|c|}{$\Delta$ Top inc. group saving rate } & \multicolumn{2}{|c|}{ Joint effect } \\
\hline & & Low90 & Top10 & Low90 & Top10 & Low90 & Top10 & Low90 & Top10 \\
\hline & & (1) & (2) & (3) & (4) & (5) & (6) & (7) & (8) \\
\hline & \multicolumn{9}{|c|}{ Exogenous input parameters } \\
\hline (A) & Income share & $74.1 \%$ & $25.9 \%$ & $68.7 \%$ & $31.3 \%$ & $74.1 \%$ & $25.9 \%$ & $68.7 \%$ & $31.3 \%$ \\
\hline \multirow[t]{2}{*}{ (B) } & Group saving rate & $6.5 \%$ & $21.4 \%$ & $6.5 \%$ & $21.4 \%$ & $6.5 \%$ & $26.9 \%$ & $6.5 \%$ & $26.9 \%$ \\
\hline & Auxiliary variables & & & & & & & & \\
\hline (C) & Total Income & \multicolumn{2}{|c|}{100} & \multicolumn{2}{|c|}{100} & \multicolumn{2}{|c|}{100} & \multicolumn{2}{|c|}{100} \\
\hline (D) & Group Income & 74.1 & 25.9 & 68.7 & 31.3 & 74.1 & 25.9 & 68.7 & 31.3 \\
\hline (E) & Group Savings & 4.8 & 5.5 & 4.5 & 6.7 & 4.8 & 7.0 & 4.5 & 8.4 \\
\hline \multirow[t]{2}{*}{ (F) } & Total Savings & \multicolumn{2}{|c|}{10.4} & \multicolumn{2}{|c|}{11.2} & \multicolumn{2}{|c|}{11.8} & \multicolumn{2}{|c|}{12.9} \\
\hline & Results & & & & & & & & \\
\hline (G) & Shares on total savings & $46 \%$ & $54 \%$ & $40 \%$ & $60 \%$ & $41 \%$ & $59 \%$ & $35 \%$ & $65 \%$ \\
\hline (H) & Aggregate saving rate & \multicolumn{2}{|c|}{$10.4 \%$} & \multicolumn{2}{|c|}{$11.2 \%$} & \multicolumn{2}{|c|}{$11.8 \%$} & \multicolumn{2}{|c|}{$12.9 \%$} \\
\hline
\end{tabular}

Top percentile group

\begin{tabular}{|c|c|c|c|c|c|c|c|c|c|}
\hline & & \multicolumn{2}{|c|}{ EVS 2008} & \multicolumn{2}{|c|}{$\Delta$ Top income share } & \multicolumn{2}{|c|}{ Top income group saving rat } & \multicolumn{2}{|c|}{ Joint effect } \\
\hline & & Low99 & Top1 & Low99 & Top1 & Low99 & Top1 & Low99 & Top1 \\
\hline & & (1) & (2) & (3) & (4) & (5) & (6) & (7) & (8) \\
\hline & \multicolumn{9}{|c|}{ Exogenous input parameters } \\
\hline (A) & Income share & $95.7 \%$ & $4.3 \%$ & $89.2 \%$ & $10.8 \%$ & $95.7 \%$ & $4.3 \%$ & $89.2 \%$ & $10.8 \%$ \\
\hline \multirow[t]{2}{*}{ (B) } & Group saving rate & $9.8 \%$ & $32.2 \%$ & $9.8 \%$ & $32.2 \%$ & $9.8 \%$ & $47.3 \%$ & $9.8 \%$ & $47.3 \%$ \\
\hline & Auxiliary variables & & & & & & & & \\
\hline (C) & Total Income & \multicolumn{2}{|c|}{100} & \multicolumn{2}{|c|}{100} & \multicolumn{2}{|c|}{100} & \multicolumn{2}{|c|}{100} \\
\hline (D) & Group Income & 95.7 & 4.3 & 89.2 & 10.8 & 95.7 & 4.3 & 89.2 & 10.8 \\
\hline (E) & Group Savings & 9.4 & 1.4 & 8.7 & 3.5 & 9.4 & 2.0 & 8.7 & 5.1 \\
\hline \multirow[t]{2}{*}{$(\mathrm{F})$} & Total Savings & \multicolumn{2}{|c|}{10.8} & \multicolumn{2}{|c|}{12.2} & \multicolumn{2}{|c|}{11.4} & \multicolumn{2}{|c|}{13.9} \\
\hline & Results & & & & & & & & \\
\hline (G) & Shares on total savings & $87 \%$ & $13 \%$ & $72 \%$ & $28 \%$ & $82 \%$ & $18 \%$ & $63 \%$ & $37 \%$ \\
\hline$(\mathrm{H})$ & Aggregate saving rate & \multicolumn{2}{|c|}{$10.8 \%$} & \multicolumn{2}{|c|}{$12.2 \%$} & \multicolumn{2}{|c|}{$11.4 \%$} & \multicolumn{2}{|c|}{$13.9 \%$} \\
\hline
\end{tabular}

Source: EVS, EVS, SOEP and tax integrated data base, own calculations.

Note: Income shares for household income are based on income shares of net equivalized income taken from Bach et al. (2016) and approximated by linear scaling based on the corresponding ratios from the EVS. In the EVS the income share of the top percentile based on household net income exceeds the top percentile's income share based on net equivalized income by 7.5 percent. Hence, we scale the income shares of net equivalized income of the other data sources by this percentage to approximate shares based on household net income.

In the second step, we only change the top decile group's saving rate and leave the other model parameters unchanged. We increase the top decile group's saving rate from 21.4 percent in the EVS scenario to 26.9 percent (column 6 , row B), which corresponds to the saving rate at the top decile group's average income value predicted by the model in Figure 7 (see also Table 3). As a result of the higher saving rate of the top decile class, its saving amount and share in total savings increase, the latter one by about 5 percentage points (column 6 , row G), i.e. roughly comparable to the increasing income share scenario in columns (3) and (4). Also, as a result of the higher saving rate of the top 
decile, the aggregate saving rate increases by slightly more than one percentage point from 10.4 to 11.8 percent (columns 5 and 6 , row $\mathrm{H}$ ).

Finally, columns (7) and (8) contain the effect of a joint change of the top decile group's income share and saving rate (rows $A$ and $B$ ). The effect on the top decile's share in aggregate savings is about 11 percentage points (column 8, row $\mathrm{G}$ ) and considerably larger than in the two single-shock scenarios described above. The aggregate saving rate is increased by about 2 percentage points, from 10.4 to 12.5 percent (columns 7 and 8 , row $\mathrm{H}$ ).

The lower part of Table 4 adds the results for the top percentile group's income share. As we are not able to estimate the saving rate of the top 1 percent based on the integrated EVS-SOEP-IncomeTaxdatabase (see Table 3 ), we decide to apply the estimate of the top percentile group's average saving rate according to the integrated EVS-SOEP-data. Here, the saving rate amounts to 47.3 percent, which is very likely to be below the value which we regard plausible for the true average saving rate in the top income percentile. Hence, our calibration is conservative at this margin. Based on the joint scenario compared to the EVS benchmark case the aggregate saving rate rises by about 3 percentage points and the top income group's share in total savings almost triples from 13 percent to 37 percent. ${ }^{17}$

\section{Summary and conclusions}

This study dealt with the estimation of saving amounts, saving rates and shares in aggregate savings for different classes of household net income and household net wealth. The analyses were based on the Sample Survey of Household Income and Expenditure (in German: Einkommens- und Verbrauchsstichprobe - EVS), a large sample containing more than 40,000 households in Germany. The most recent sample, which provides data for the year 2013 has not been published before spring 2016. These data provide, among others, detailed information on household income, wealth expenditure categories and household savings. The information contained therein can be regarded as of very high quality for a number of reasons. Most prominently, data on household savings are derived from detailed records of incomes and expenditures that sample households are asked to protocol in a so-called housekeeping book during a three-months period. Thus, the usual disadvantages of surveys like memory gaps, framing, etc. are mostly avoided. Moreover, savings do not have to be derived as the difference between income and consumption, which can be considered another source of measurement error.

Our results can be summarized as follows. Household savings are highly concentrated along both the income and the wealth distribution. While the average annual savings amount of the lower half of the income distribution in 2013 lies at approximately -300 euros (i.e. these households do not save at all), the top income percentile's savings amount is nearly 60,000 euros per year. Although relative income

\footnotetext{
${ }^{17}$ It might be plausible to assume that due to the upward-shift of income groups resulting from the augmentation of the income scale at the top, the average saving rate of the whole population (and not solely for the top income group) increases. However, the rise of the average saving rate of the comparably poor households will not be substantial. Moreover, assuming a shift of the saving rate for the 99 percent of households not belonging to the top percentile group from 9.8 percent to 11 percent would imply a savings share of the top percentile group of 34 percent, which is still a substantial increase in the conditional concentration of household savings.
} 
and wealth positions are positively associated, the conditional distribution of household savings along the wealth distribution is considerably less concentrated. The mean annual savings amount within the lower half of the wealth distribution is about 1,500 euros in 2013, whereas the average yearly savings amount of the top wealth percentile is about 24,000 euros.

Accordingly, saving rates increase with income and wealth. In 2013 the average saving rate of the lower half of the income distribution is -1.6 percent while the top income percentile's mean saving rate equals 35 percent. The average saving rate in the lower half of the wealth distribution is about 5.7 percent in 2013. In contrast, households in the top wealth percentile save slightly more than one fourth of their net incomes.

Most clearly, the high concentration of household savings is reflected in the group-specific shares on total household savings which in 2013 equal 60 percent for the top income decile whereas the lower half of the income distribution actually does not save at all. The lower half of the wealth distribution makes up for about 17 percent of total household savings. The top wealth decile's share amounts to nearly 30 percent. A comparison of these findings over time indicates a more or less steady increase of the conditional concentration of household savings across the income and wealth distribution.

Finally, our discussion of the implications of the top income cut-off in the EVS on the distribution of household savings indicates that the above reported figures may considerably underestimate saving rates at the top of the income distribution as well as the concentration of household savings as measured by the top income groups' shares in total savings. According to our extrapolations, not correcting for the bias of the missing rich involves an underestimation of the top decile group's average saving rate of about 5.5 percentage points and an underestimation of the top percentile group's average saving rate of more than 15 percentage points. Moreover, the share in total savings of the top income decile group is likely to be underestimated by approximately 10 percentage points and the respective share in total savings for the top percentile income group by nearly 25 percentage points. Finally, we find the aggregate saving rate to be underestimated by about two to three percentage points. Of course, these results are based on a number of assumptions and have to be treated with caution.

The results of this study can be used in applications analyzing endogenous resource accumulation (such as in Krämer, 2015 or van Treeck, 2014) that contribute to explore the issue on whether mutual stimulation between income flows and wealth stocks can help explaining rising inequality. This type of models requires a sensible empirical calibration for which it is necessary to estimate a whole set of parameters like capital returns, top income and top wealth shares as well as information on the distribution of household savings up to the top tail of the income and wealth distribution. A promising way for further research would therefore be to estimate the remaining model parameters like capital returns and use them to calibrate the respective models, as this would help to get more insight into the economic circumstances that can cause endogenous wealth accumulation and potentially further concentration of income among households. 


\section{References}

Adler, M.; Schmid, K. (2013): Factor Shares and Income Inequality. Evidence from Germany, 2002-2008. Journal of Applied Social Science Studies, 133(2):121-132.

Aspromourgos, T. (2015): Thomas Piketty, the future of capitalism and the theory of distribution: a review essay. Metroeconomica, 66(2):284-305.

Atkinson, A. (2009). Factor Shares: The Principal Problem of Political Economy? Oxford Review of Economic Policy, 25(1):316.

Bach, S.; Corneo, G.; Steiner, V. (2009): From Bottom to Top: The Entire Income Distribution in Germany, 1992-2003. Review of Income and Wealth, 55(2): 303-330.

Bach, S.; Corneo, G.; Steiner, V. (2013): Effective Taxation of Top Incomes in Germany, 1992-2002. German Economic Review 14:115-137.

Bach, S.; Thiemann, A.; Zucco, A. (2015): The Top Tail of the Wealth Distribution in Germany, France, Spain, and Greece. DIW Discussion Papers, No. 1502.

Bach, S.; Beznoska, M.; Steiner, V. (2016): Wer trägt die Steuerlast in Deutschland? Verteilungswirkungen des deutschen Steuer- und Transfersystems. DIW Berlin: Politikberatung kompakt 112.

Bartels, C.; Jenderny, K. (2014): The role of capital income for top incomes shares in Germany. Discussion Papers 2014/32, Free University Berlin, School of Business \& Economics.

Behringer, J.; Theobald, T.; van Treeck, T. (2014): Income and Wealth Distribution in Germany: A Macro-Economic Perspective. IMK Report 99e-2014, IMK at the Hans Boeckler Foundation, Macroeconomic Policy Institute.

Biewen, M.; Juhasz, A. (2012): Understanding rising inequality in Germany, 1999/2000-2005/06. Review of Income and Wealth, 58(4):622-647.

Börsch-Supan, A.; Reil-Held, A.; Schunk, D. (2006): Das Sparverhalten deutscher Haushalte: Erste Erfahrungen mit der Riesterrente. Gutachten für das Bundesministerium für Bildung und Forschung im Rahmen des Vorhabens „Bildungssparen“. Mannheim Research Institute for the Economics of Aging (MEA).

Brenke, K.; Wagner, G. (2013): Ungleiche Verteilung der Einkommen bremst das Wirtschaftswachstum. Wirtschaftsdienst, 93(2):110-116.

Brenke, K.; Grabka, M. (2011): Schwache Lohnentwicklung im letzten Jahrzehnt.In: DIW Wochenbericht, 78(45):3-15.

Coppola, M.; Lamla, B. (2013): Saving and Old-Age Provision in Germany (SAVE): Design and Enhancements, Schmollers Jahrbuch, 133(1):109-117.

Corneo, G. (2015): Kreuz und quer durch die deutsche Einkommensverteilung. In: Perspektiven der Wirtschaftspolitik, 16(2):109-126.

Davies, J. (1993): The distribution of wealth in Canada. Research in Economic Inequality, 4, 159-180.

Davies, J.; Shorrocks, A. (1999): The distribution of wealth. Handbook of Income Distribution. Edited by A. B. Atkinson and F. Bourguignon. Volume 1, Chapter 11: 223-254.

Destatis (2008): Wirtschaftsrechnungen. Einkommens- und Verbrauchsstichprobe. Aufgabe, Methode und Durchführung. Fachserie 15, Heft 7, Wiesbaden, Statistisches Bundesamt.

Drechsel-Grau, M.; Schmid, K. (2014): Consumption-savings decisions under upward-looking comparisons. Journal of Economic Behavior \& Organization, Elsevier, 106(C):254-268.

Drechsel-Grau, M.; Peichl, A.; Schmid, K. (2015): Einkommensverteilung und gesamtwirtschaftliche Entwicklung in Deutschland: Spitzeneinkommen - ein Missing-Link. Wirtschaftsdienst, 95(10):684-688.

Fuchs-Schündeln, N. (2008): The Response of Household Saving to the Large Shock of German Reunification. American Economic Review 2008, 98(5):1798-1828. 
Horn, G.; Gechert, S.; Rehm, M.; Schmid, K. (2014): Wirtschaftskrise unterbricht Anstieg der Einkommensungleichheit. IMK Report No. 97.

IAW (2011): Aktualisierung der Berichterstattung über die Verteilung von Einkommen und Vermögen in Deutschland für den 4. Armuts- und Reichtumsbericht der Bundesregierung. Institute for Applied Economic Research (IAW), Tübingen.

IAW und ZEW (2015): Analyse der Verteilung von Einkommen und Vermögen in Deutschland. Unveröffentlichtes Gutachten, Tübingen, Mannheim.

IMF (2015): Causes and Consequences of Income Inequality: A Global Perspective, IMF Staff Discussion Note 15/13, International Monetary Fund, Washington, D.C.

Kalina, T.; Weinkopf, C. (2012): Niedriglohnbeschäftigung 2010: Fast jede/r Vierte arbeitet für Niedriglohn. IAQ Report, No.1.

Klär, E.; Slacalek, J. (2006): Entwicklung der Sparquote in Deutschland: Hindernis für die Erholung der Konsumnachfrage. DIW Wochenbericht, 73(40):537-543.

Krämer, H. (2015): Make no mistake, Thomas. In: Bofinger, P., Horn, G.A., Schmid, K.D., van Treeck, T. (Hrsg.): Thomas Piketty und die Verteilungsfrage. Analysen, Bewertungen und wirtschaftspolitische Implikationen für Deutschland. Berlin: SE Publishing, S.37-71.

Mau, S.; Heuer, J. (2016): Wachsende Ungleichheit als Gefahr für nachhaltiges Wachstum. Wie die Bevölkerung über soziale Unterschiede denkt. Beitrag im Rahmen des Projekts „Gute Gesellschaft - Soziale Demokratie 2017plus“ der Fridrich-EbertStiftung.

OECD (2015): In It Together: Why Less Inequality Benefits All, OECD Publishing, Paris.

Piketty, Thomas (2013): Capital in the Twenty-First Century. Harvard University Press

Rehm, M.; Schmid, K.; Wang, D. (2014): Why Has Inequality in Germany not Risen Further After 2005? ECINEQ Working Paper, No. 333.

Schmid, K.; Drechsel-Grau, M.; Peichl, A. (2015): Factor shares, personal income distribution and top incomes in Germany. Income inequality - Quo Vadis? IMK Report, No. 108e.

Schmid, K.; Stein, U. (2013): Explaining Rising Income Inequality in Germany, 1991-2010. IMK Study, No. 32.

van Treeck, T. (2014): Zur Bedeutung unterschiedlicher Sparquoten für Pikettys „Gesetze des Kapitalismus“. Einige einfache Simulationen, http://verteilungsfrage.org/2014/07/zur-bedeutung-unterschiedlicher-sparquoten-fuer-piketty/

Vermeulen, P. (2014): How fat is the top tail of the wealth distribution? Working Paper Series 1692, European Central Bank.

Westermeier, C.; Grabka, M. (2015): Significant Statistical Uncertainty over Share of High Net Worth Households. DIW Economic Bulletin, DIW Berlin, German Institute for Economic Research, 5(14/15):210-219. 


\section{Appendix}

Table 5: Summary statistics, yearly saving amount by income and wealth deciles

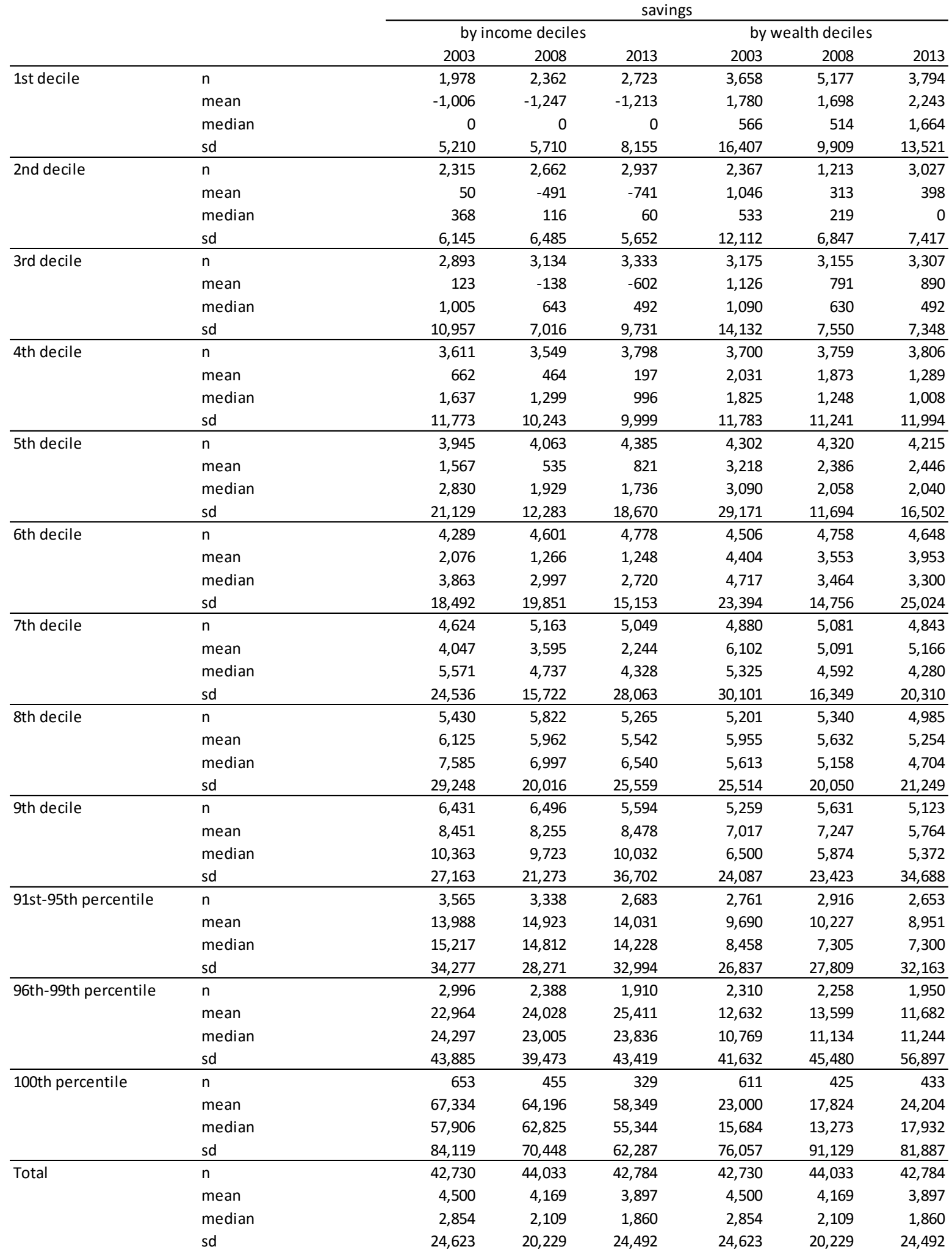

Source: EVS, own calculations. Calculations based on 2013 euros. 
Table 6: Summary statistics, yearly saving rates by income and wealth deciles

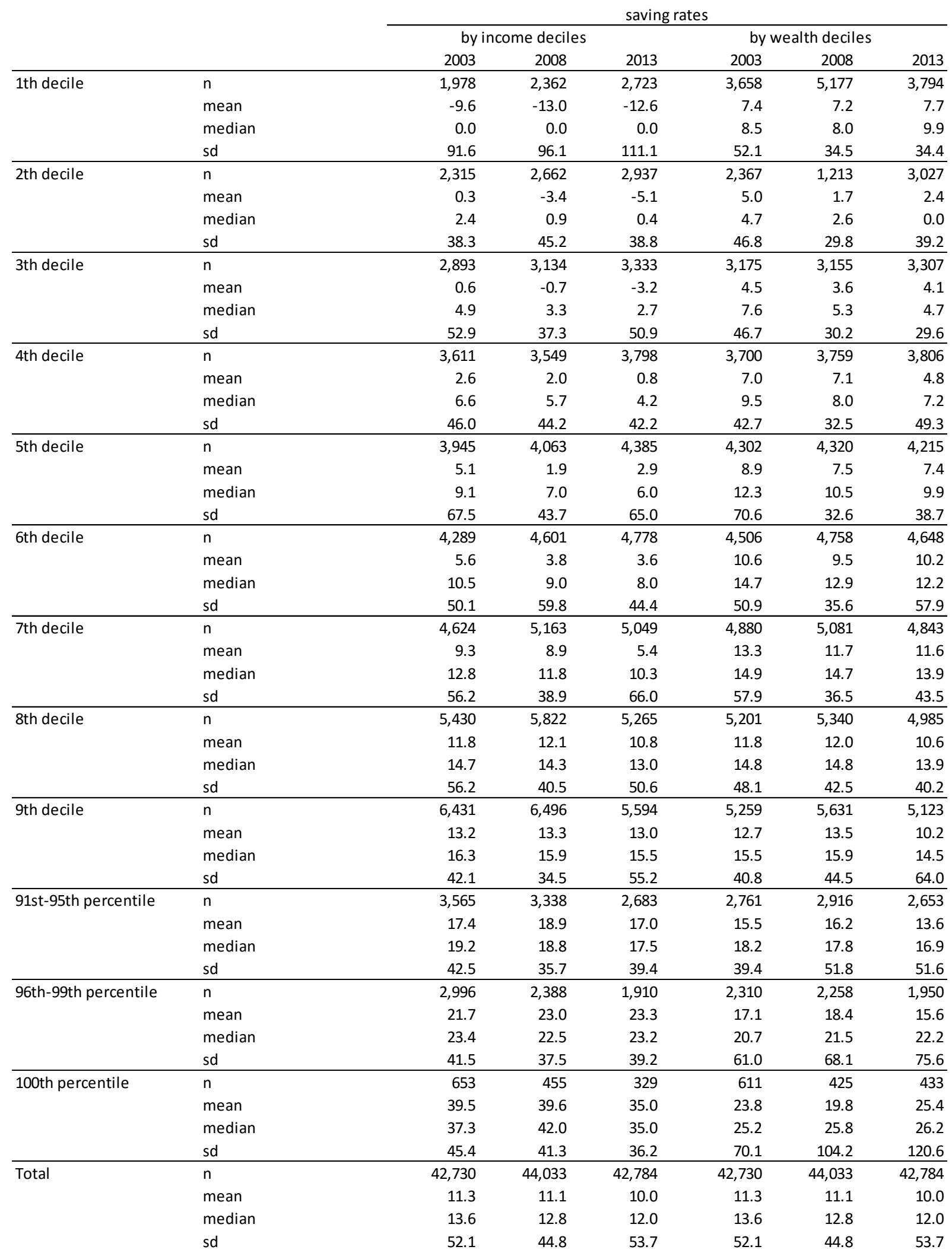

Source: EVS, own calculations. Calculations based on 2013 euros. 
Figure 8: Shares in aggregate savings across income groups

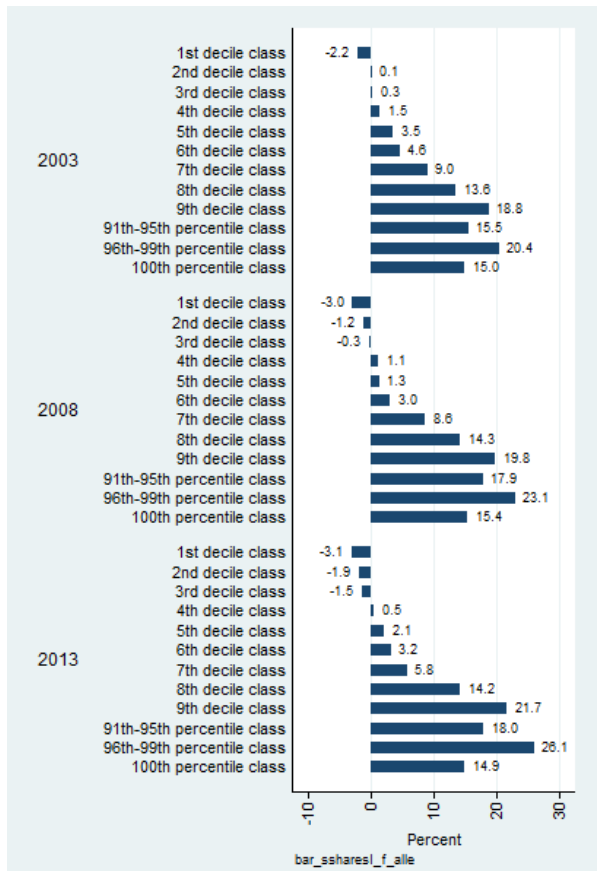

Source: EVS, own calculations. Calculations based on 2013 euros.
Figure 9: Shares in aggregate savings across wealth groups

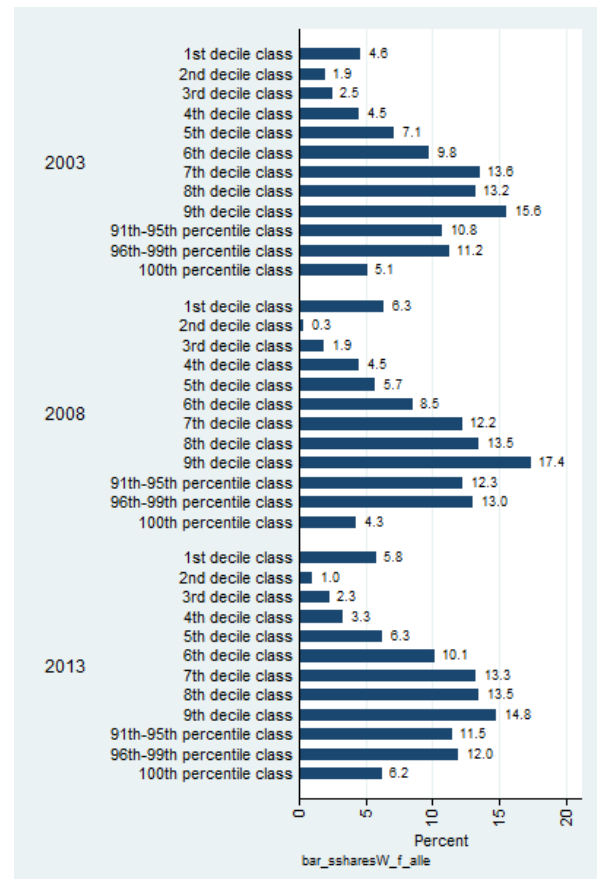

Source: EVS, own calculations. Calculations based on 2013 euros. 
Table 7: Estimated yearly saving amounts with 95 percent confidence intervals by income deciles

\begin{tabular}{|c|c|c|c|c|c|c|c|c|c|}
\hline & \multicolumn{3}{|c|}{2003} & \multicolumn{3}{|c|}{2008} & \multicolumn{3}{|c|}{2013} \\
\hline & Savings & $\begin{array}{l}\text { Lower ci } \\
\text { limit }\end{array}$ & $\begin{array}{l}\text { Upper ci } \\
\text { limit }\end{array}$ & Savings & $\begin{array}{l}\text { Lower ci } \\
\text { limit }\end{array}$ & $\begin{array}{l}\text { Upper ci } \\
\text { limit }\end{array}$ & Savings & $\begin{array}{l}\text { Lower ci } \\
\text { limit }\end{array}$ & $\begin{array}{l}\text { Upper ci } \\
\text { limit }\end{array}$ \\
\hline $1^{\text {st }}$ decile class & $-1,006$ & $-1,339$ & -726 & $-1,247$ & $-1,487$ & $-1,027$ & $-1,213$ & $-1,521$ & -915 \\
\hline $2^{\text {nd }}$ decile class & 50 & -253 & 358 & -490 & -730 & -246 & -740 & -952 & -524 \\
\hline $3^{\text {rd }}$ decile class & 123 & -418 & 591 & -137 & -405 & 98 & -602 & -971 & -236 \\
\hline $4^{\text {th }}$ decile class & 661 & 210 & 1,090 & 464 & 125 & 826 & 197 & -143 & 517 \\
\hline $5^{\text {th }}$ decile class & 1,567 & 946 & 2,147 & 534 & 57 & 967 & 820 & 283 & 1,527 \\
\hline $6^{\text {th }}$ decile class & 2,076 & 1,465 & 2,679 & 1,266 & 672 & 1,806 & 1,248 & 698 & 1,701 \\
\hline $7^{\text {th }}$ decile class & 4,046 & 3,244 & 4,885 & 3,595 & 3,091 & 4,097 & 2,243 & 1,380 & 3,030 \\
\hline $8^{\text {th }}$ decile class & 6,125 & 5,300 & 7,106 & 5,961 & 5,304 & 6,639 & 5,541 & 4,769 & 6,390 \\
\hline $9^{\text {th }}$ decile class & 8,451 & 7,606 & 9,231 & 8,255 & 7,586 & 8,900 & 8,477 & 7,375 & 9,503 \\
\hline $91^{\text {th }}-95^{\text {th }}$ percentile class & 13,988 & 12,759 & 15,250 & 14,922 & 13,608 & 16,380 & 14,031 & 12,539 & 15,445 \\
\hline $96^{\text {th }}-99^{\text {th }}$ percentile class & 22,963 & 21,062 & 24,813 & 24,027 & 21,913 & 25,935 & 25,410 & 23,248 & 27,675 \\
\hline $100^{\text {th }}$ percentile class & 67,334 & 59,992 & 76,241 & 64,195 & 56,770 & 71,365 & 58,349 & 50,643 & 65,531 \\
\hline$N$ & & 42,730 & & & 44,033 & & & 42,784 & \\
\hline
\end{tabular}

Source: EVS, own calculations. Confidence intervals bootstrapped with 1,000 replications. Calculations based on 2013 euros. 
Table 8: Estimated yearly saving amounts with 95 percent confidence intervals by wealth deciles

\begin{tabular}{|c|c|c|c|c|c|c|c|c|c|}
\hline & \multicolumn{3}{|c|}{2003} & \multicolumn{3}{|c|}{2008} & \multicolumn{3}{|c|}{2013} \\
\hline & Savings & $\begin{array}{c}\text { Lower ci } \\
\text { limit }\end{array}$ & $\begin{array}{l}\text { Upper ci } \\
\text { limit }\end{array}$ & Savings & $\begin{array}{c}\text { Lower ci } \\
\text { limit }\end{array}$ & $\begin{array}{l}\text { Upper ci } \\
\text { limit }\end{array}$ & Savings & $\begin{array}{c}\text { Lower ci } \\
\text { limit }\end{array}$ & $\begin{array}{l}\text { Upper ci } \\
\text { limit }\end{array}$ \\
\hline $1^{\text {st }}$ decile class & 1,780 & 1,285 & 2,321 & 1,697 & 1,416 & 1,983 & 2,242 & 1,777 & 2,659 \\
\hline $2^{\text {nd }}$ decile class & 1,045 & 598 & 1,491 & 313 & -123 & 685 & 397 & 182 & 666 \\
\hline $3^{\text {rd }}$ decile class & 1,125 & 616 & 1,592 & 790 & 497 & 1,051 & 890 & 613 & 1,137 \\
\hline $4^{\text {th }}$ decile class & 2,030 & 1,555 & 2,525 & 1,873 & 1,466 & 2,326 & 1,289 & 898 & 1,717 \\
\hline $5^{\text {th }}$ decile class & 3,218 & 2,285 & 4,162 & 2,385 & 1,996 & 2,752 & 2,445 & 1,911 & 2,941 \\
\hline $6^{\text {th }}$ decile class & 4,404 & 3,656 & 5,180 & 3,552 & 3,081 & 4,037 & 3,953 & 3,227 & 4,804 \\
\hline $7^{\text {th }}$ decile class & 6,102 & 5,222 & 7,118 & 5,091 & 4,551 & 5,641 & 5,166 & 4,547 & 5,780 \\
\hline $8^{\text {th }}$ decile class & 5,954 & 5,242 & 6,639 & 5,632 & 5,000 & 6,262 & 5,253 & 4,572 & 5,904 \\
\hline $9^{\text {th }}$ decile class & 7,017 & 6,304 & 7,716 & 7,246 & 6,502 & 7,956 & 5,764 & 4,655 & 6,944 \\
\hline $91^{\text {th }}-95^{\text {th }}$ percentile class & 9,690 & 8,450 & 10,825 & 10,227 & 9,048 & 11,568 & 8,951 & 7,423 & 10,460 \\
\hline $96^{\text {th }}-99^{\text {th }}$ percentile class & 12,632 & 10,643 & 14,703 & 13,599 & 11,417 & 15,757 & 11,681 & 8,551 & 14,477 \\
\hline $100^{\text {th }}$ percentile class & 23,000 & 17,080 & 30,517 & 17,823 & 7,705 & 27,959 & 24,204 & 15,488 & 33,421 \\
\hline$N$ & & 42,730 & & & 44,033 & & & 42,784 & \\
\hline
\end{tabular}

Source: EVS, own calculations. Confidence intervals bootstrapped with 1,000 replications. Calculations based on 2013 euros. 
Table 9: Estimated yearly saving rates with 95 percent confidence intervals by income deciles

\begin{tabular}{|c|c|c|c|c|c|c|c|c|c|}
\hline & \multicolumn{3}{|c|}{2003} & \multicolumn{3}{|c|}{2008} & \multicolumn{3}{|c|}{2013} \\
\hline & Saving rate & $\begin{array}{c}\text { Lower ci } \\
\text { limit }\end{array}$ & $\begin{array}{l}\text { Upper ci } \\
\text { limit }\end{array}$ & Saving rate & $\begin{array}{c}\text { Lower ci } \\
\text { limit }\end{array}$ & $\begin{array}{l}\text { Upper ci } \\
\text { limit }\end{array}$ & Saving rate & $\begin{array}{c}\text { Lower ci } \\
\text { limit }\end{array}$ & $\begin{array}{l}\text { Upper ci } \\
\text { limit }\end{array}$ \\
\hline $1^{\text {st }}$ decile class & -9.6 & -12.9 & -6.9 & -13.0 & -15.6 & -10.7 & -12.6 & -15.9 & -9.5 \\
\hline $2^{\text {nd }}$ decile class & 0.3 & -1.6 & 2.3 & -3.4 & -5.0 & -1.7 & -5.1 & -6.5 & -3.6 \\
\hline $3^{\text {rd }}$ decile class & 0.6 & -2.0 & 2.9 & -0.7 & -2.1 & 0.5 & -3.2 & -5.1 & -1.2 \\
\hline $4^{\text {th }}$ decile class & 2.6 & 0.8 & 4.3 & 2.0 & 0.5 & 3.5 & 0.8 & -0.6 & 2.2 \\
\hline $5^{\text {th }}$ decile class & 5.1 & 3.1 & 6.9 & 1.9 & 0.2 & 3.5 & 2.9 & 1.0 & 5.3 \\
\hline $6^{\text {th }}$ decile class & 5.6 & 4.0 & 7.3 & 3.8 & 2.0 & 5.4 & 3.6 & 2.0 & 4.9 \\
\hline $7^{\text {th }}$ decile class & 9.3 & 7.4 & 11.2 & 8.9 & 7.6 & 10.1 & 5.4 & 3.3 & 7.2 \\
\hline $8^{\text {th }}$ decile class & 11.8 & 10.2 & 13.7 & 12.1 & 10.8 & 13.5 & 10.8 & 9.3 & 12.5 \\
\hline $9^{\text {th }}$ decile class & 13.2 & 11.8 & 14.4 & 13.3 & 12.3 & 14.4 & 13.0 & 11.3 & 14.6 \\
\hline $91^{\text {th }}-95^{\text {th }}$ percentile class & 17.4 & 15.9 & 18.9 & 18.9 & 17.3 & 20.8 & 17.0 & 15.2 & 18.7 \\
\hline $96^{\text {th }}-99^{\text {th }}$ percentile class & 21.7 & 20.0 & 23.5 & 23.0 & 21.0 & 24.9 & 23.3 & 21.3 & 25.3 \\
\hline $100^{\text {th }}$ percentile class & 39.5 & 35.3 & 44.5 & 39.6 & 35.0 & 43.8 & 35.0 & 30.5 & 39.1 \\
\hline$N$ & & 42,730 & & & 44,033 & & & 42,784 & \\
\hline
\end{tabular}

Source: EVS, own calculations. Confidence intervals bootstrapped with 1,000 replications. Calculations based on 2013 euros. 
Table 10: Estimated yearly saving rates with 95 percent confidence intervals by wealth deciles

\begin{tabular}{|c|c|c|c|c|c|c|c|c|c|}
\hline & \multicolumn{3}{|c|}{2003} & \multicolumn{3}{|c|}{2008} & \multicolumn{3}{|c|}{2013} \\
\hline & Saving rate & $\begin{array}{c}\text { Lower ci } \\
\text { limit }\end{array}$ & $\begin{array}{l}\text { Upper ci } \\
\text { limit }\end{array}$ & Saving rate & $\begin{array}{l}\text { Lower ci } \\
\text { limit }\end{array}$ & $\begin{array}{l}\text { Upper ci } \\
\text { limit }\end{array}$ & Saving rate & $\begin{array}{l}\text { Lower ci } \\
\text { limit }\end{array}$ & $\begin{array}{l}\text { Upper ci } \\
\text { limit }\end{array}$ \\
\hline $1^{\text {st }}$ decile & 7.4 & 5.4 & 9.5 & 7.2 & 6.0 & 8.3 & 7.7 & 6.2 & 9.1 \\
\hline $2^{\text {nd }}$ decile & 5.0 & 2.9 & 7.1 & 1.7 & -0.7 & 3.7 & 2.4 & 1.1 & 4.0 \\
\hline $3^{\text {rd }}$ decile & 4.5 & 2.5 & 6.3 & 3.6 & 2.3 & 4.8 & 4.1 & 2.8 & 5.1 \\
\hline $4^{\text {th }}$ decile & 7.0 & 5.4 & 8.6 & 7.1 & 5.6 & 8.7 & 4.8 & 3.3 & 6.3 \\
\hline $5^{\text {th }}$ decile & 8.9 & 6.5 & 11.3 & 7.5 & 6.3 & 8.6 & 7.4 & 5.9 & 8.8 \\
\hline $6^{\text {th }}$ decile & 10.6 & 8.8 & 12.5 & 9.5 & 8.2 & 10.7 & 10.2 & 8.4 & 12.5 \\
\hline $7^{\text {th }}$ decile & 13.3 & 11.5 & 15.4 & 11.7 & 10.6 & 12.9 & 11.6 & 10.3 & 12.8 \\
\hline $8^{\text {th }}$ decile & 11.8 & 10.4 & 13.1 & 12.0 & 10.7 & 13.3 & 10.6 & 9.2 & 11.8 \\
\hline $9^{\text {th }}$ decile & 12.7 & 11.5 & 13.9 & 13.5 & 12.2 & 14.7 & 10.2 & 8.3 & 12.2 \\
\hline $91^{\text {th }}-95^{\text {th }}$ percentile & 15.5 & 13.7 & 17.2 & 16.2 & 14.5 & 18.2 & 13.6 & 11.5 & 15.8 \\
\hline $96^{\text {th }}-99^{\text {th }}$ percentile & 17.1 & 14.6 & 19.7 & 18.4 & 15.7 & 21.2 & 15.6 & 11.6 & 19.0 \\
\hline $100^{\text {th }}$ percentile & 23.8 & 18.0 & 30.8 & 19.8 & 8.6 & 30.5 & 25.4 & 16.5 & 34.7 \\
\hline$N$ & & 42,730 & & & 44,033 & & & 42,784 & \\
\hline
\end{tabular}

Source: EVS, own calculations. Confidence intervals bootstrapped with 1,000 replications. Calculations based on 2013 euros. 
Figure 10: Shares in total net household income across income groups

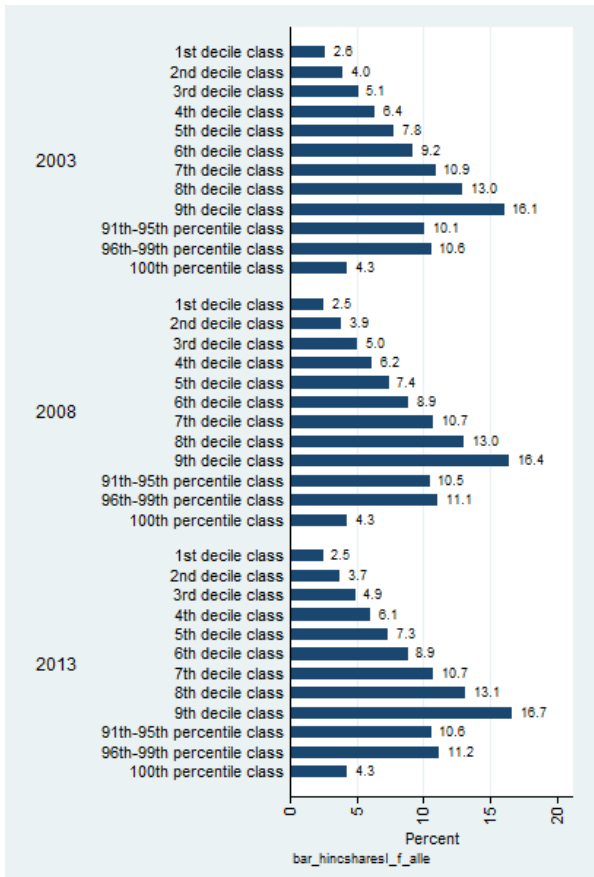

Source: EVS, own calculations. Calculations based on 2013 euros.

Figure 12: Shares in total net household income across wealth groups

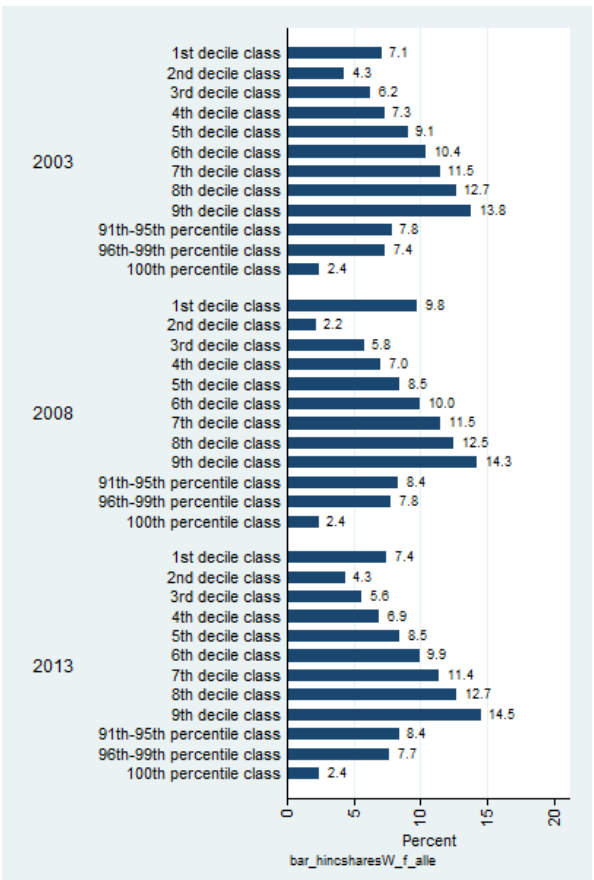

Source: EVS, own calculations. Calculations based on 2013 euros.
Figure 11: Shares in total net household wealth across wealth groups

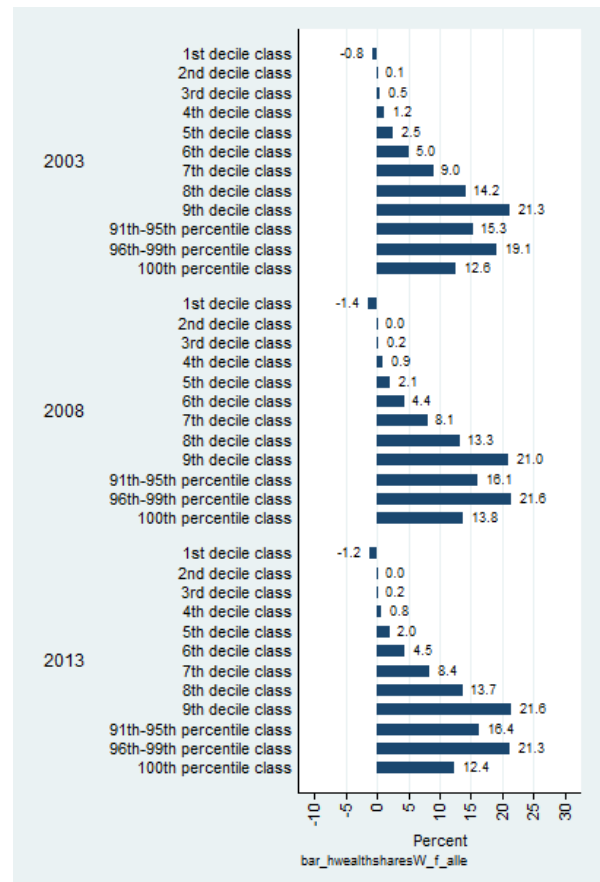

Source: EVS, own calculations. Calculations based on 2013 euros.

Figure 13: Shares in total net household wealth across income groups

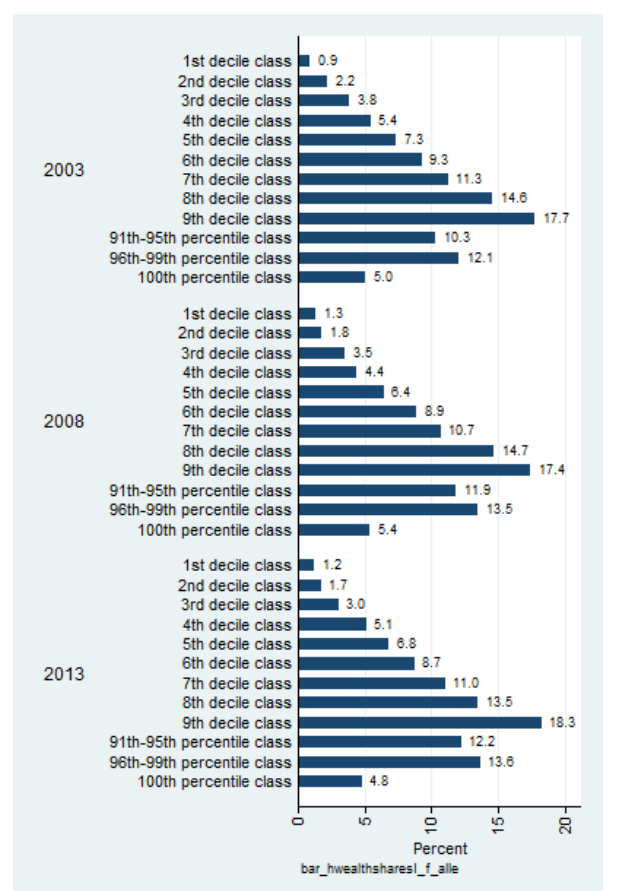

Source: EVS, own calculations. Calculations based on 2013 euros. 
Table 11: Distribution of income conditional on wealth, 2013

\begin{tabular}{|c|c|c|c|c|c|c|c|c|c|c|c|c|}
\hline \multicolumn{13}{|c|}{ Wealth decile } \\
\hline & & 1 & 2 & 3 & 4 & 5 & 6 & 7 & 8 & 9 & 10 & Total \\
\hline \multirow{10}{*}{ 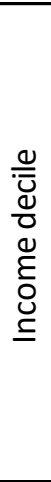 } & 1 & 13.7 & 40.6 & 21.7 & 11.0 & 5.5 & 3.1 & 1.7 & 1.0 & 1.1 & 0.8 & 10.0 \\
\hline & 2 & 14.1 & 23.1 & 21.3 & 15.6 & 10.9 & 7.2 & 4.1 & 2.0 & 1.1 & 0.6 & 10.0 \\
\hline & 3 & 13.7 & 14.5 & 17.4 & 16.8 & 13.7 & 9.1 & 6.9 & 4.1 & 2.6 & 1.2 & 10.0 \\
\hline & 4 & 13.0 & 8.6 & 12.2 & 15.4 & 13.4 & 12.1 & 9.3 & 8.3 & 4.9 & 3.0 & 10.0 \\
\hline & 5 & 12.2 & 5.4 & 9.6 & 12.5 & 13.1 & 12.8 & 11.9 & 10.5 & 7.9 & 4.1 & 10.0 \\
\hline & 6 & 10.1 & 3.6 & 6.9 & 10.1 & 12.8 & 13.7 & 12.1 & 13.1 & 11.3 & 6.3 & 10.0 \\
\hline & 7 & 8.2 & 2.1 & 5.4 & 8.3 & 11.5 & 12.4 & 13.3 & 15.0 & 14.2 & 9.6 & 10.0 \\
\hline & 8 & 7.9 & 1.2 & 3.2 & 5.7 & 9.3 & 13.0 & 15.6 & 14.8 & 15.9 & 13.7 & 10.0 \\
\hline & 9 & 4.8 & 0.6 & 1.8 & 3.2 & 6.4 & 10.5 & 15.3 & 16.6 & 19.6 & 21.2 & 10.0 \\
\hline & 10 & 2.5 & 0.3 & 0.6 & 1.5 & 3.6 & 6.2 & 9.9 & 14.6 & 21.4 & 39.5 & 10.0 \\
\hline & & & & & & & & & & & & 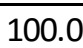 \\
\hline
\end{tabular}

Source: EVS, own calculations. Table entries denote column percentages. 


\section{Impressum}

Publisher: Hans-Böckler-Stiftung, Hans-Böckler-Str. 39, 40476 Düsseldorf, Germany Phone: +49-211-7778-331, IMK@boeckler.de, http://www.imk-boeckler.de

IMK Study is an online publication series available at:

http://www.boeckler.de/imk 5023.htm

\section{ISSN: $1861-2180$}

The views expressed in this paper do not necessarily reflect those of the IMK or the Hans-Böckler-Foundation.

All rights reserved. Reproduction for educational and non-commercial purposes is permitted provided that the source is acknowledged. 